NBER WORKING PAPERS SERIES

FOREIGN DIRECT INVESTMENT IN THE U.S.:

CHANGES OVER THREE DECADES

Robert E. Lipsey

Working Paper No. 4124

NATIONAL BUREAU OF ECONOMIC RESEARCH 1050 Massachusetts Avenue

Cambridge, MA 02138

July 1992

Financial support from the Ford Foundation is gratefully acknowledged. This paper is part of NBER's research program in International Trade and Investment. Any opinions expressed are those of the author and not those of the National Bureau of Economic Research. 


\title{
FOREIGN DIRECT INVESTMENT IN THE U.S.: CHANGES OVER THREE DECADES
}

\begin{abstract}
U.S. direct investment inflows in the 1980 s were almost half the world's total. Even this large inflow leaves foreign firms employing less than 5 per cent of the U.S. labor force, but twice that share in manufacturing. That increase is related to the internationalization of production by foreign firms more than to competitive weakness of U.S. firms.

Foreign affiliates import more relative to their exports than U.S. firms but are moving closer to the behavior of U.S. firms. The trade balances of both are sensitive to exchange rates.

The financing of foreign direct investment from retained earnings dropped almost to zero in the 1980s. One reason is the rapid growth of this investment and another is its low profitability.
\end{abstract}

Robert E. Lipsey

NBER

269 Mercer Street, 8th Floor

New York, NY 10003

and

Queens College and the Graduate Center

City University of New York 


\title{
Foreign Direct Investment in the U.S.:
}

\author{
Changes Over Three Decades*
}

Robert E. Lipsey

\section{Historical Background}

It has been a characteristic of the foreign investment history of the United States as far back as there is any statistical record, and probably earlier also, that while inward investment was largely in portfolio form, outward investment was mainly direct investment. That is, the outward investment mostly involved control of foreign operations by U.S. firms, while the inward investment took the form of lending by foreigners to government agencies or enterprises that were controlled by Americans. The contrast between the two sides of the investment balance sheet can be summarized in the Table 1, to the extent that the historical record permits the distinction to be made.

The individual figures here often rely on weak statistical foundations and the fluctuations in the ratios should not be taken very seriously. For example, the sharp rise in the share of direct investment in the U.S. outward total between 1929 and 1935 to a large extent reflects the fact that, in the data

* This paper was prepared for the NBER Conference on Direct Investment in May 1992. I am indebted to Qing Zhang for statistical and computer assistance and to Robert Lawrence, R. David Belli, and other participants in the conference for comments and suggestions for improving the paper. 
Table 1

Share of Direct Investment in Foreign Private Investment in the U.S. and U.S. Private Investment Abroad

Selected Years, 1897 to 1960

Investment in the U.S.
Per Cent

$\begin{array}{lll}1897 & 93 & \text { NA } \\ 1908 & 65 & \text { NA } \\ 1914 & 75 & 18 \\ 1919 & 56 & 23 \\ 1924 & 50 & - \\ 1929 & 44 & 16 \\ 1935 & 59 & 25 \\ 1940 & 60 & 22 \\ 1950 & 62 & 19 \\ 1960 & 65 & 17\end{array}$

Source: Lipsey (1988) and U.S. Bureau of the Census (1975), based mainly on data from Lewis (1938). 
source, bond holdings were adjusted to market value in 1935 while direct investments were not, although they too must have fallen substantially in market value. The contrast between inward and outward investment is clear, however. Direct investment was almost always more than half the outward investment total but never more than a quarter of the inward investment.

The large decline in the share of direct investment on the outward side between 1919 and 1929 has had its counterpart in more recent years, as we discuss later. That decline reflected a tremendous expansion in portfolio lending, concentrated in Latin America to a much larger extent than ever before. Much of that portfolio investment disappeared in defaults and price depreciation during the 1930s.

Since direct investment is a transfer more of technological or management skills than of capital, it may seem surprising that there was so little inflow into the United States during the 19th century, when several European countries must have possessed superior technology and skills. One explanation may be that the transfer of skills took a different form when transportation and communication were so slow and primitive compared to that in recent years. Because of the difficulty of controlling foreign enterprises from a home base, much of the transfer of knowledge took the form of human migration, either to establish enterprises in the United States or to manage them after they were first established. Also, as Mira Wilkins (1989) points out in her recent study of foreign investment in the United States before 1914, 
the distinction between direct and portfolio investment was not always a sharp one. Even portfolio investors sometimes intervened in the management of American firms when things went badly. And many of the earlier direct investments in the United States were what she refers to as "free-standing" enterprises, differing from most U.S. direct investment in recent years in that they were owned by foreigners but not by foreign firms. They were not subsidiaries of multinational firms, as is typical now, although they were sometimes parts of loose networks trading with each other and sometimes sharing expertise in technical fields. Such enterprises were probably much more likely over time to turn into domestic U.S. firms with the migration of their owners or adaptation to local conditions in the United States than are the current subsidiaries of multinational enterprises.

II. The Magnitude of Foreign Direct Investment in the U.S. II.A. The U.S. Share in the World's Stocks and Flows

The dominant role of the United States as a supplier of direct investment to other countries before the 1970s is reflected in the fact that U.S. outward investment accounted for over half of the developed world's stock of direct investment in 1967 and 1971, with the next most important direct investor, the U.K., owning only about $15-17$ per cent, and no other single country accounting for more than 6 per cent (UN, 1978, Table III-32). On the other side of the account, foreign direct investment in the United States was 
only 9 per cent of the world's total stock in 1967 and 11 per cent in 1975 (UN 1978, Table III-33).

The U.S. share of direct investment outflows since the late 1960 s is described in Table 2. It was well over half the developed country total in the 1960 s, and stayed at or close to half through the 1970s. In the second half of the 1970s the U.S. was still responsible for almost half the developed country outflow and more than 40 per cent of that of the whole world. Then, in the first half of the 1980s, direct investment from the U.S. fell to less than 20 per cent of the world outflow, and by the latest period had gone below 15 per cent.

The opposite change took place on the inflow side. The direct investment inflow to the United States was less than 10 per cent of the total inflow to developed countries in 1960 and $1965-66,17$ per cent in 1967-69, and jumped to about a quarter in 1973-75 and over a third in 1975-80. The U.S. share of world inflows, only about 15 per cent in the early 1970 s, reached over a quarter in the late 1970 s, almost 40 per cent in $1981-85$ and 46 per cent in 1985-89.

The consequence of these declining U.S. shares of outflows and increasing shares of inflows can be seen in the shares of direct investment stocks. By 1988 the U.S. held 35 per cent of the world stock of outward investment and 31 per cent of the stock of inward investment. The U.S. share of outward investment would probably be considerably higher if either of the 
Table 2

U.S. Share of Developed Countries' and World Direct Investment Inflows and Outflows, 1960 and 1965 to 1990

\begin{tabular}{|c|c|c|c|}
\hline \multicolumn{2}{|c|}{ Outflows } & \multicolumn{2}{|c|}{ Inflows } \\
\hline $\begin{array}{l}\text { Developed } \\
\text { Countries }\end{array}$ & World & $\begin{array}{l}\text { Developed } \\
\text { Countries }\end{array}$ & World \\
\hline
\end{tabular}

\begin{tabular}{ll}
1960 & 57 \\
$1965-66$ & 64 \\
$1967-69$ & 56 \\
$1970-72$ & 512 \\
$1973-75^{a}$ & 43 \\
$1973-75^{b}$ & 48 \\
$1975-80$ c & \\
$1975-80^{d}$ & \\
$1981-85$ & \\
$1980-84$ & \\
$1985-89$ & \\
$1986-90$ & \\
& \\
\hline & \\
acComparable to $1970-72$ \\
bComparable to $1975-80$ \\
CComparable to $1973-75$ \\
dComparable to $1981-85$
\end{tabular}

57.6

64.9

56.8

51.9

43.8

48.9

47.7

6.2

2.2

16.7

10.4

26.2

24.3

7.2

16.8

18.8

26.2

42.4

35.4

24.5

19.1

39.3

31.8

17.1

42.2

13.8

46.0

Source: Appendix Table 1. 
alternative valuations discussed below were used, since the U.S. investments are older than those of most other countries. And the U.S. share of inward investment would be considerably smaller if the reporting of inward investment by other countries were more complete.

These figures by themselves seem to imply that the United States has in recent years sharply cut back its former role as the major supplier of direct investment capital to the rest of the world. It has, instead, apparently come to absorb a very high proportion of the world's supply of direct investment capital.

While there is some truth to this summary, there are also some questionable aspects to it. Since the U.S. was the leading foreign direct investor in the early post-WWII decades, many of its holdings are wellestablished foreign firms, and the further flow of U.S. direct investment capital to foreign countries comes largely from the retained earnings of these companies. While the U.S. reports these retained earnings as flows of direct investment, many other countries do not, and the share of the U.S. in outflows is therefore probably exaggerated. Since many other countries fail to report the reinvested earnings in their inward investment accounts, the U.S. share on the inward side is probably also overstated.

\section{II.B. U.S. Inward and Outward Direct Investment Stocks and Flows}

Since the U.S. was much more of an exporter than an importer of direct investment for many years, as described above, the stock of foreign 
direct investment in the U.S. was small compared to U.S. holdings abroad. In 1950, for example, the inward stock was less than 30 per cent as large as the outward stock, measured by book values, and in 1966, after the rapid growth in U.S. outward direct investment, it was less than 20 per cent (Table 3). As foreign direct investment in the U.S. began to grow rapidly in the years after 1977, the book value ratio rose, to the point where in 1990 the foreign direct investment in the U.S. appeared about as large as the U.S. direct investment abroad, a startling change in a little over a decade.

As this near-reversal of the direct investment balance took place, along with the widely publicized story that the U.S. had gone in a few years from a major creditor position to being "the world's greatest debtor," a number of observers expressed skepticism about the significance of the book value data. These are basically historical cost valuations, but those for U.S. direct investment abroad are affected by exchange rate changes, since many book values are translated into U.S. dollars from foreign currencies using current exchange rates. Since U.S. direct investment abroad was much older on average than foreign investment in the U.S., it seemed likely that it had been made at much lower than current prices and, for that and other reasons, was greatly undervalued (Eisner and Pieper, 1990, Ulan and Dewald, 1989). That impression was reinforced by the fact that foreign income from direct investment in the U.S. was much smaller than U.S. income on direct investment abroad, well under half in 1990, for example (Di Lullo, 1991, 
Table 3

Value of Stock of Foreign Direct Investment in the U.S.

as Per Cent of the Value of the Stock of U.S. Direct Investment Abroad Selected Years, 1950 to 1990

\begin{tabular}{|c|c|c|c|c|}
\hline & \multicolumn{2}{|l|}{$\begin{array}{l}\text { Book } \\
\text { Value }\end{array}$} & \multirow{2}{*}{$\begin{array}{l}\begin{array}{c}\text { Current } \\
\text { Cost }\end{array} \\
\text { Total }\end{array}$} & \multirow{2}{*}{$\begin{array}{r}\text { Market } \\
\text { Value }\end{array}$} \\
\hline & $\begin{array}{c}\text { Excluding } \\
\text { Neth. Antilles } \\
\text { Finance Affiliates }\end{array}$ & Total & & \\
\hline 1950 & 28.8 & 28.8 & & \\
\hline 1966 & 17.5 & 17.5 & & \\
\hline 1977 & 23.5 & 23.7 & 22.7 & \\
\hline 1982 & 54.7 & 60.0 & 46.3 & 58.3 \\
\hline 1985 & 75.5 & 80.2 & 59.9 & 59.9 \\
\hline 1988 & 90.9 & 93.7 & 73.8 & 57.6 \\
\hline 1990 & 95.4 & 95.8 & 77.9 & 74.3 \\
\hline
\end{tabular}

Source: Appendix Tables 2 and 3 and Scholl (1991), Table 3. 
Table 5). In response to these doubts, the BEA undertook the calculation of some alternative measures. One, referred to as the "current-cost" method is based on a revaluation of tangible assets. The main feature is a revaluation of plant and equipment using a perpetual inventory calculation from past expenditures. Land and inventories are also revalued to a rough measure of current prices. The "market-value" method is a revaluation of the equity part of direct investment on the basis of movements in stock prices (Landefeld and Lawson, 1991). ${ }^{1}$

Two aspects of the story seem fairly clear. One is that foreign direct investment in the U.S. is still considerably smaller than U.S. direct investment abroad. The other is that the foreign investment in the U.S. grew much more

1 Both of these adjustments are extremely crude. Even if they were not, there is no reason to expect them to give similar results. In the case of U.S. corporations, for which the data are far better, the "adjusted book value," akin to the current value used here, ranged from more than 20 per cent below to almost 90 per cent above the market value of the equity derived from stock prices between 1929 and 1958 (Goldsmith and Lipsey, 1963, Vol. I, Table 25), and from 30 per cent below to more than twice as high between 1954 and 1977 (Cagan and Lipsey, 1978, Table 2-3). 
rapidly than U.S. investment abroad after 1977 , not only in percentage terms but, by some measures, in dollar terms as well. Thus, as compared with the 1950s, 1960s, and 1970s, the U.S. was an exceptionally attractive location for foreign companies in the 1980 s relative to the attractiveness of foreign locations for U.S. companies. This was the case despite the very high price of U.S. assets during part of this period as the exchange value of the U.S. dollar reached its peak in 1984, and early 1985. However, the period after 1977 also includes two periods of low exchange values of the dollar, one around 1980 and one after 1985.

While the expected effects of exchange rate changes on trade by affiliates are clear, and are described below, the effects on investment flows are ambiguous. For example, a high exchange value of the U.S. dollar makes foreign production facilities more economical relative to those in the U.S., but the incentive for a U.S. firm to invest in such facilities would be stronger if the product were very tradable than if it were a service or a relatively nontradable good. In addition the high value of the dollar would reduce the price of a foreign facility in dollar terms, so that an increase in physical investment might be offset by the decline in the dollar price of the foreign assets and result in a decline in investment outflows denominated in dollars unless there were a high elasticity of demand for productive assets, or a high elasticity of substitution between U.S. and foreign assets. 


\section{II.C. Foreign-owned Firms' Shares of the U.S. Economy}

The rapid growth of foreign direct investment in the U.S. should be compared with some measures of the size of the U.S. economy. By some indicators, this comparison places the foreign operations in perspective as even now a small part of the economy. One such measure is the ratio of the stock of foreign direct investment to the assets of U.S. corporations (Table 4). The stock of foreign direct investment looks small by this standard, but the rapid growth after 1977 does stand out.

If we confine our attention to the nonfinancial sector, foreign direct investment appears more important. That is partly because foreign ownership is less important in finance and partly because the finance sector's assets include a large amount of holdings of the equity and debt of other sectors and of the finance sector itself. There is much less duplication, in this sense, in the nonfinancial sector's assets. The foreign share here more than doubled between 1950 and 1980 or 1960 and 1980, and then much more than doubled during the 1980s. Thus the growth of the foreign investment share accelerated during the 1980s.

In a sense, this comparison between foreign investment and assets is a misleading one because the numerator and denominator are different concepts. More appropriate comparisons might be for shares of output or shares of inputs into production, such as labor or capital, but these are more limited in their time spans. 
Table 4

Book Value of Foreign Direct Investment in the U.S. as Per Cent of Assets of U.S. Corporations Selected Years, 1950 to 1988

A11

Corporations
0.6

0.6

0.5

0.7

0.7

1.2

1.5

1.6

1.9

2.1
Nonfinancial

Corporations

Source: Appendix Tables 3 and 4. 
A calculation of the share of U.S. manufacturing industry assets under foreign control in 1980 and 1988 was made by Orr (1991). As part of the calculation he estimated what the foreign share of motor vehicle industry assets would be if Japanese-owned auto production operations, listed under the wholesale trade industry in the Department of Commerce data, were transferred to the manufacturing category. An affiliate would be listed in wholesale trade in the official data if its wholesale trade activities were larger than the manufacturing activity. Since value of sales, rather than value added, is the criterion, the method tends to put into wholesale trade affiliates that would be in manufacturing by a value added or employment criterion because ratios of sales to value added or employment added are much larger in wholesale trade than in manufacturing. Orr's estimates for the foreign share in manufacturing assets were (per cent):

$\begin{array}{rr}1980 & 8.5 \\ 1988 & 14.3\end{array}$

Even with the estimated motor vehicle industry assets added, the shares in the transportation equipment industry, 4.4 per cent in 1980 and 5.9 per cent in 1988 , were well below the average for manufacturing.

A comparison of gross product, excluding banks, suggests something less than a doubling of the foreign share in U.S. output between 1977 and 1987 , 


\section{Per Cent}

1977

1981

1987
2.3

4.2

4.3

Source: Lowe (1990), Table 4

somewhat slower than that indicated by the direct investment data. Another comparison, this time on the input side, for employment (Table 5), shows that the levels are fairly small, but the growth has been rapid: the ratio tripled between 1974 and 1989.

The employment shares of foreign firms vary greatly among sectors: they are much higher in goods production, particularly mining and manufacturing than in service sectors (Table 6). The sector ratios are subject to the problem that establishments are classified differently in the two sources. The aggregate U.S. data are classified by industry of establishment while the data for foreign affiliates are consolidated into a total for all affiliates of a single firm and classified by the predominant industry. The most likely effect is to move trade and service operations into manufacturing, although some manufacturing operations, such as Japanese auto plants, may be classified under wholesale trade because the distribution activities related to importing may be so large. The mining share is almost certainly exaggerated by the inclusion of petroleum distribution operations with the refining activities of foreign-owned petroleum companies. 


\section{Table 5}

Employment in Nonbank U.S. Affiliates of Foreign Companies as Per Cent of U.S. Private Non-agricultural Employment

Selected Years, 1974 to 1989

$\begin{array}{ll}1974 & 1.6 \\ 1977 & 1.8 \\ 1980 & 2.7 \\ 1982 & 3.3 \\ 1984 & 3.5 \\ 1987 & 3.8 \\ 1988 & 4.4 \\ 1.989 & 4.9\end{array}$

Source: Appendix Tables 5 and 6 
Table 6

Employment in U.S. Affiliates of Foreign Corporations as Per Cent of Total U.S. Private Sector Employment, by Broad Industry Groups, Selected Years, 1974 to 1989

\begin{tabular}{|c|c|c|c|c|c|c|c|c|}
\hline & 1974 & 1977 & 1980 & 1982 & 1984 & 1987 & 1988 & 1989 \\
\hline $\begin{array}{l}\text { Mining } \\
\text { Manufacturing } \\
\text { GOODS PRODUCTION }\end{array}$ & $\begin{array}{r}16.8 \\
2.8 \\
3.3\end{array}$ & $\begin{array}{r}13.0 \\
3.5 \\
3.9\end{array}$ & $\begin{array}{r}12.4 \\
5.5 \\
5.8\end{array}$ & $\begin{array}{r}14.5 \\
6.7 \\
7.1\end{array}$ & $\begin{array}{r}16.3 \\
7.2 \\
7.6\end{array}$ & $\begin{array}{r}19.9 \\
8.2 \\
8.6\end{array}$ & $\begin{array}{r}17.6 \\
9.5 \\
9.9\end{array}$ & $\begin{array}{l}25.8 \\
11.0 \\
11.5\end{array}$ \\
\hline $\begin{array}{l}\text { Construction } \\
\text { Transp. \& publ. util. } \\
\text { GOODS, coNSTRUCTION, } \\
\text { TRANSP. \& PUB. UTIL. }\end{array}$ & $\begin{array}{l}0.2 \\
1.0 \\
2.5\end{array}$ & $\begin{array}{l}0.3 \\
\underline{0.5} \\
2.9\end{array}$ & $\begin{array}{l}1.0 \\
0.7 \\
4.3\end{array}$ & $\begin{array}{l}1.3 \\
1.1 \\
\end{array}$ & $\begin{array}{l}1.0 \\
1.2 \\
5.5\end{array}$ & $\begin{array}{l}1.0 \\
\underline{1.8} \\
\end{array}$ & $\begin{array}{l}1.1 \\
2.4 \\
7.1\end{array}$ & $\begin{array}{l}1.5 \\
\underline{3.3} \\
8.3\end{array}$ \\
\hline $\begin{array}{l}\text { Wholesale trade } \\
\text { Retail trade } \\
\text { Finance, Insur., Real Estate } \\
\text { Services } \\
\text { TRADE\& SERVICES }\end{array}$ & $\begin{array}{l}2.8 \\
1.0 \\
1.1^{\mathrm{C}} \\
\frac{0.3}{1.0}\end{array}$ & $\begin{array}{l}3.2 \\
1.0 \\
1.1 \\
0.2 \\
1.0\end{array}$ & $\begin{array}{l}4.1 \\
2.0 \\
2.1 \\
\frac{0.5}{1.6}\end{array}$ & $\begin{array}{l}5.3 \\
2.6 \\
2.3 \\
0.6 \\
2.1\end{array}$ & $\begin{array}{l}5.3 \\
2.7 \\
2.2 \\
0.9 \\
2.2\end{array}$ & $\begin{array}{l}5.5 \\
3.0 \\
3.1 \\
1.2 \\
2.5\end{array}$ & $\begin{array}{l}6.5 \\
4.3 \\
3.6 \\
\frac{1.5}{3.2}\end{array}$ & $\begin{array}{l}6.3 \\
4.2 \\
3.6 \\
1.5 \\
3.1\end{array}$ \\
\hline
\end{tabular}

ancluding petroleum

Banking included in denominator but not in numerator

Including banking, would be 1.8 per cent

Source: Appendix Tables 6 and 7 
The development that has been drawn the most public comment is the growth of the foreign share in manufacturing, from minor levels in 1974 to over 10 per cent of employment in 1989 . What is equally notable is the pervasiveness of the growth in foreign shares, which more than doubled in every broad industry group shown here. While this growth is often viewed from the U.S. perspective as a sign of American weakness, it was also a part of a general move toward internationalization of production by firms all around the world, in which foreign firms began to imitate the internationalization that large American firms pioneered in the 1950s and 1960s (Lipsey, 1989). Even at the end of the period, the foreign share in U.S. manufacturing employment was not high compared to that in most developed countries except Japan and the Nordic countries.

The growth in the foreign share of U.S. manufacturing employment has affected all the main groups within the manufacturing sector, but it has gone much further in some groups than in others (Table 7). Over the whole period, the foreign share of employment in chemicals has been much higher than that in any other industry group, a surprising fact in view of the strong position of American chemical companies in world trade. In fact, the foreign shares among these industry groups do not seem to bear any relation to the competitive strength of American companies; they are no higher in the groups in which American firms are relatively weak, such as foods, metals, and 


\section{Table 7}

Employment in U.S. Manufacturing Affiliates of Foreign Corporations as Per Cent of U.S. Manufacturing Employment, by Industry

Selected Years, 1974 to 1989

$\begin{array}{lrrrr} & \underline{1974} & \underline{1980} & \underline{1987} & \underline{1989} \\ \text { All Manufacturing } & 2.8 & 5.5 & 8.2 & 11.0 \\ \text { Food \& kindred products } & 4.4 & 7.0 & 8.8 & 14.7 \\ \text { Chemicals } & 10.8 & 25.7 & 38.6 & 41.2 \\ \text { Metals } & 3.2 & 4.1 & 7.4 & 12.6 \\ \text { Machinery, exc. elect. } & 1.9 & 4.7 & 5.4 & 11.4 \\ \text { Elect. mach. \& equip. } & 2.8 & 8.3 & 10.5 & 15.5 \\ \text { Transp. equip. } & .0 & 3.4 & 2.7 & 3.1 \\ \text { Other manuf. } & 2.1 & 2.9 & 5.8 & 6.9\end{array}$

Source: Appendix Tables 6 and 7 
miscellaneous manufactures, than in industries where U.S. firms hold strong positions, such as chemicals and machinery. It may be that the foreign shares are high in chemicals and machinery because the nature of these industries leads firms from all countries to be multinational, and that it would be higher if U.S. firms were not strong in these fields.

Two points should be made about particular industries. The fact that the foreign share is so low in transport equipment and has not risen since 1980 , although it clearly did increase before that, reflects two factors. One is the lack of foreign ownership in the aircraft industry. That may partly reflect the connection with national defense, but the international dominance of U.S. firms must also be a factor. A second reason for the low share, especially in view of the failure of the share to rise after 1980 , may be a classification scheme that places some manufacturing employment by foreign car producers under wholesale trade because that is the predominant activity of the U.S. subsidiaries.

The high foreign share in chemicals probably reflects the characterization of DuPont as foreign-owned although it is not owned by a foreign chemical company and is not part of a foreign-based chemicals network. It is different in this respect from other foreign-owned chemical operations, such as the Swiss-owned pharmaceutical firms and HoechstCelanese. The inclusion of DuPont, if it is included, has a major effect: it would probably account for something in the neighborhood of 100,000 
employees out of the reported 443,000. If all of DuPont, including petroleum operations, is combined into this chemicals group, the degree of exaggeration is increased by the fact that employees in the petroleum operations are in the numerator, but not in the denominator of the fraction. However even without DuPont, chemicals would still be the industry group with the largest foreign share, by a large margin.

The large role of foreign firms in the chemical industry has long historical roots, based on foreign, particularly German, companies' early lead in chemical technologies. Mira Wilkins (1989) reported that "Foreign direct investment had more impact on the pre-World War I American chemical industry than on any other U.S. industry...in no other industry were Europeans so far in advance of Americans; in no other single industry was the foreign technological contribution so dramatic." (p. 383) and that "... by 1914 few branches of the U.S. chemical industry were untouched by foreign direct investment. No other American industry was as influenced by European business enterprises" (p. 411). "In the pre-war chemical and dye industries, German interests were supreme" according to Lewis (1938, p. 102).

That large foreign, particularly German, role persisted despite the confiscation and sale to Americans of German patents and property by the Alien Property Custodian during World War I and a second round of confiscations during and after World War II. Among the German holdings before World War I, according to Wilkins (1989, Chapter 11), were Rohm 
and Haas, Heyden Chemical, Merck \& Co., Hoechst, and Bayer. During World War II, the Alien Property Custodian vested \$51.4 million in enemyowned property, mostly German, that included American Potash and Chemical Corp. and General Aniline and Film Corp. (U.S. Dept. of Commerce, 1948, pp. 93 and 99), and in the years after World War II, vested another $\$ 58$ million, part of which consisted of "...two large rayon manufacturing companies..." (U.S. Dept. of Commerce, 1950, pp. 130-131 and 160).

In 1989, almost a quarter of foreign firms' employment in chemicals (even with DuPont's employment included, if it is; almost 30 per cent if we assume it is included and remove it) was in German-controlled firms. These firms must possess some strong and persistent technological advantages to retain their position in the U.S. and to keep regaining it after it has been cut off.

Another view of the changing importance of foreign-owned affiliates in U.S. manufacturing is provided by shares in plant and equipment expenditures. While the employment measure in a sense overweights labor intensive activities, the plant and equipment measure gives a high weight to capital intensive activities and, possibly, to relatively new operations. The foreign affiliate shares may be exaggerated by the inclusion of intra-company transfers of plant and equipment that would not enter the denominator.

Since 1974, the foreign share in manufacturing plant and equipment expenditure appears to have multiplied greatly (Table 8 ). 
Table 8

Plant and Equipment Expenditures by U.S. Manufacturing Affiliates of Foreign Corporations as Per Cent of Total U.S. Expenditure, by Industry Selected Years, 1974 to 1989

\begin{tabular}{lrrrr} 
& $\underline{1974}$ & $\underline{1980}$ & $\underline{1987}$ & $\underline{1989}$ \\
\cline { 2 - 2 } & 6.2 & 8.9 & 12.3 & 16.3 \\
Foods & 5.5 & 9.2 & 7.9 & 11.0 \\
Chemicals & 15.6 & 23.7 & 33.5 & 50.4 \\
Metals & 10.5 & 7.8 & 12.4 & 26.8 \\
Machinery, exc. elect. & & 4.0 & 6.5 & 13.2 \\
Elect. mach. \& equip. & 2.0 & 10.4 & 9.4 & 10.2 \\
Transport. equip. & & 1.3 & 10.3 & 6.0 \\
Other manuf. & 4.2 & 9.2 & 9.0 & 10.6
\end{tabular}

Source: Appendix Tables 11 and 12 
In several respects, the capital expenditure data confirm the story in the employment data. The trend in the foreign share was very strongly upward, although not quite as steep. The rise in the importance of the foreign firms was evident in all the industry groups. The role of foreign-owned firms was highest in chemicals throughout the period. In general, the foreign role is greater in capital expenditures than in employment, but foods and electrical machinery were exceptions in this regard. In the case of the chemicals industry, the possible inclusion of DuPont in the 1987 and 1989 data could be a major part of the high ratios. In 1989, for example, DuPont reported over $\$ 3$ billion in plant and equipment expenditures in the United States (Annual Report, p. 49), a third of the more than $\$ 9$ billion for all chemical affiliates of foreign companies in Appendix Table 12. DuPont reported $\$ 600$ million of capital expenditures in oil and gas operations in the U.S. that year, but some may have been expensed, and therefore not included in the capital expenditure figures.

III. Foreign-Owned Affiliates in the U.S. and U.S. Trade III. A. The Role of Foreign-owned Affiliates in U.S. Exports and Imports By the end of the 1980s, foreign-owned affiliates had come to play a large role in U.S. merchandise trade. They exported $\$ 84$ billion in goods from the United States and imported $\$ 170$ billion, 23 per cent of U.S. exports and over a third of imports. These amounts seem very large relative to the 
shares of foreign firms in U.S. production or employment, but they are so large because much of these firms' export and import activity is as intermediaries, trading in goods produced by other firms, not necessarily foreign. More than half of the foreign firms' exports, for example, are by foreign trading firms, classified as wholesale trade affiliates. They deal in metals and minerals, and in farm products and other raw materials. The former group is mainly Japanese and the latter is split between Japanese and French affiliates. In neither group is it likely that much of the exports come from the foreign firms' own production. One might guess that while the foreign firms' intermediation provides some gains in efficiency, the exports would not change greatly if these trading operations were closed. On the other hand, the exports by wholesale affiliates in motor vehicles and machinery, mainly Japanese, could have been the output of manufacturing operations by the same firms in the U.S.

Imports by foreign-owned wholesalers are mostly of manufactured products that would probably be imported anyway. The importation via affiliates is presumably more efficient for the foreign manufacturers and probably adds to their profits or their market shares.

If we assume that the exports and imports of manufacturing affiliates are more related to their own production activities than are those of trade affiliates, the trade of the manufacturing affiliates may be more likely to reflect the effects of the direct investment. The amounts are still large, $\$ 31$ 
billion of exports and $\$ 39$ billion of imports by manufacturing affiliates in 1989 (U.S. Dept. of Commerce, 1991c, Tables G-5 and G-6). The exports were $101 / 2$ per cent of our rough estimate of exports produced by the manufacturing sector, and $121 / 2$ per cent of all exports in SITC groups 4 through 9. Not all of the trade by manufacturing affiliates is of manufactured products, but the 1987 data (U.S. Dept. of Commerce 1990, Tables G-10 and G-16) suggest that only about 5 per cent of exports and between 5 and 10 per cent of imports are crude materials and fuels.

One contentious topic with respect to foreign firms' operations has been their impact, if any, on U.S. trade. A suspicion is often expressed, echoing earlier complaints against U.S. operations in Canada, for example, that foreign-owned firms are disinclined to export, but have much higher propensities to import than U.S. firms do. It is not clear that such propensities, if they existed, would have any implications for U.S. trade in general, but we can ask whether the foreign operations are very distinctive in their trade behavior.

It is true that foreign-owned manufacturing operations export more than they import. At the earliest date for which we have data, 1974, their exports were about two-thirds of their imports; by 1989 , exports were 80 per cent of imports. 


\section{Merchandise Exports as Per Cent of Imports by} U.S. Manufacturing Affiliates of Foreign Firms Selected Years, 1974 to 1989

$\begin{array}{rr}1974 & 66 \\ 1982 & 104 \\ 1986 & 62 \\ 1989 & 80\end{array}$

\section{Source: Appendix Table 8}

The trade behavior of the foreign affiliates should be viewed against the changes that took place in these years in U.S. trade as a whole. In 1974, U.S. exports and imports, other than those of foreign-owned affiliates, were equal. There was a strong downward trend in the export/import ratio, however, until by 1989 it was a little lower than the ratio for foreign manufacturing affiliates. Thus, to the extent that the data for non-affiliates reflects the general macroeconomic circumstances of the United States, exports from the United States by foreign affiliates were facing unfavorable conditions.

III.B. Changing exchange rates and the trade of foreign-owned U.S. firms

One possible explanation for the change in foreign affiliate export/import ratios is that the foreign affiliates have in some sense "grown up" and have become less dependent on their parent companies for supplies and components. That may be the case, but there are reasons to be skeptical. One is that foreign direct investment in the U.S. has been growing so fast that the average age of the foreign-owned enterprises is probably not rising. 
Another is that the time pattern suggests the influence of another factor: the U.S. exchange rate. The export/import ratio was highest in 1982, after the low point in the exchange value of the dollar, and the ratio was at a low point in 1986, after the peak in the value of the U.S. dollar. That influence of the exchange rate is at least mildly confirmed by equation 1 , which relates the export/import ratio to the effective exchange rate of the dollar, lagged one year, and a time trend.

(1) $(\mathrm{EXAFF} / \mathrm{IMAFF})_{\mathrm{t}}=-12.91-4.29 \mathrm{EER}_{\mathrm{t}-1}+.007 \mathrm{YR} \quad \overline{\mathrm{R}}^{2}=.131$ (0.76) (1.98)

where $\quad$ EXAFF $=$ Affiliate exports X 100

IMAFF $=$ Affiliate imports

$\mathrm{EER}=$ U.S. effective exchange rate as reported in the Federal Reserve Bulletin

$\mathrm{YR}=$ Year

t-statistics in parentheses

The time trend is not significant, but it is positive, as we would expect from any maturing of the investments. The coefficient of the effective exchange rate variable is negative, as we expect, and statistically significant, as it would be if a high price of the dollar discouraged exports by these affiliates and encouraged imports by them.

If we suspect some J-curve effects on the import side, we might include both current and lagged exchange rate changes, as in equation 2 .

(2) $(\mathrm{EXAFF} / \mathrm{IMAFF})_{\mathrm{t}}=-13.90+6.60 \mathrm{EER}_{\mathrm{t}}-9.28 \mathrm{EER}_{\mathrm{t}-1}+.0075 \mathrm{YR}$ 
The use of both current and lagged effective exchange rates greatly improves the explanation of the changes in affiliate export/import ratios and suggests that both current and lagged responses to exchange rates are important. This evidence fits with the finding in Lipsey (1991) that foreign affiliates exports/sales ratios to a large degree and imports/sales ratios to a small degree, respond to effective exchange rate changes.

The movements of the effective exchange rate over this period, together with a time trend term, explain the export/import ratio of the U.S., other than foreign affiliates, to a far greater degree than they do the affiliate trade ratios, as can be seen in equation 3 .

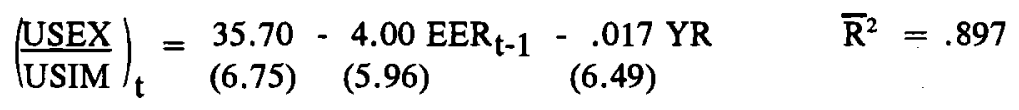

where USEX $=$ U.S. exports of merchandise minus exports by foreign affiliates in the U.S.

$$
\begin{aligned}
& \text { USIM }= \text { U.S. imports of merchandise minus imports by } \\
& \text { foreign affiliates. }
\end{aligned}
$$

The effective exchange rate coefficient is about the same for foreign affiliates' trade (in equation 1) and for other U.S. trade (in equation 3), but the trends are very different; the U.S. trade ratio has a strong downward trend over this period. If we add the current exchange rate to the lagged exchange rate of equation 3 we find that the current rate has the expected negative coefficient, but it is not statistically significant. It does, however, improve the fit of the equation slightly. 
(4) $\left(\frac{\mathrm{USEX}}{\mathrm{USIM}}\right)_{\mathrm{t}}=\begin{array}{ccc}35.53 & -1.11 \mathrm{EER}_{\mathrm{t}}-4.84 \mathrm{EER}_{\mathrm{t}-1}-\underset{(6.59)}{(6.85)}(1.20) & (5.03)\end{array}$

$$
\overline{\mathrm{R}}^{2}=.901
$$

The ratio for non-affiliate U.S. trade, incorporating the effect of lagged exchange rate changes in combination with a trend term, goes a considerable way towards explaining the trade ratio for affiliates (equation 5).

(5) $\left(\frac{\text { EXAFF }}{\text { IMAFF }}\right)_{t}=\underset{(2.91)}{-62.9}+\underset{(3.51)}{(1.33}\left(\frac{\text { USEX }}{\text { USIM }}\right)_{t}+\underset{(2.93)}{.032}$ YR

$$
\overline{\mathrm{R}}^{2}=.444
$$

In this case the time trend is again positive, implying that given the factors affecting non-affiliate trade, or U.S. trade in general, the trade ratio for affiliates was rising; the trend for affiliates was toward typical U.S. behavior.

A stronger explanation of the affiliate trade ratio is achieved by adding the contemporary exchange rate to equation 5 (equation 6).

(6) $\left(\frac{\text { EXAFF }}{\text { IMAFF }}\right)_{t}=\underset{(4.36)}{-78.4}+\underset{(5.22)}{1.83}\left(\frac{\text { USEX }}{\text { USIM }}\right)_{t}+\underset{(4.36)}{.039 \mathrm{YR}_{(2.76)}}+\underset{t .28 \mathrm{EER}_{\mathrm{t}}}{4}$

$$
\overline{\mathrm{R}}^{2}=.652
$$

The positive contemporary exchange rate coefficient here suggests a J-curve effect, only for foreign-owned affiliates or larger for them than for other U.S. firms. 
IV. The Country and Industry Composition of Foreign Direct Investment in the U.S.

IV.A. The Industry Composition of Investment

The longest continuous series on the industry composition of foreign direct investment in the U.S. are for the direct investment position. While that measure is related to the composition of sales, assets, employment, or other measures of activity, the relationship is not always close. A given amount of assets or employment can be financed mainly by parent funds or mainly by borrowing in the U.S. itself, and the extent of financing through borrowed funds could vary from industry to industry. In addition, the historical data on the U.S. position classify the origin of the investment by the country of direct, or immediate, foreign ownership rather than by the country of the ultimate owner, as in some of the recent data.

One shift in the industry composition of direct investment in the U.S. was the growth in importance of goods industries and decline in service industries from 1950 through the early 1970s (Table 9). That change was subsequently reversed, so that the shares in 1990 were quite similar to those of 1960. Within these categories, petroleum first rose greatly in importance and then declined even more, ending up at less than $10 \%$ of the total. The decade and a half after 1960 also saw a rapid growth of wholesaling and a decline in finance investment, both of which were subsequently reversed, leaving both groups at the end slightly below their importance in 1974 . One 
Table 9

Distribution of U.S.Direct Investment Position, by Broad Industry Groups, Selected Years, 1950 to 1990

\begin{tabular}{|c|c|c|c|c|c|c|}
\hline & \multicolumn{6}{|c|}{ FOREIGN DIRECT INVESTMENT IN THE U, $S$. } \\
\hline & $\underline{1950}$ & 1960 & 1966 & $\underline{1974}$ & $\underline{1982}$ & $\underline{1990}$ \\
\hline Petroleun & $11.9^{\mathrm{a}}$ & $17.9^{a}$ & $19.2^{\mathrm{a}}$ & 27.2 & 14.9 & 9.6 \\
\hline Manufacturing & $\underline{33.6}$ & 37.8 & $\underline{41.8}$ & 36.3 & 37.2 & 40.2 \\
\hline GOODS PRODUCTION & 45.5 & 55.7 & 61.1 & $66.3^{b}$ & $49.8^{b}$ & $51.0^{b}$ \\
\hline \multirow{2}{*}{\multicolumn{7}{|c|}{$\begin{array}{l}\text { Transp., commun. \& } \\
\text { public util. }\end{array}$}} \\
\hline & NA & 5.9 & NA & 1.5 & 1.2 & 1.7 \\
\hline Wholesale trade & NA & 9.2 & NA & 18.3 & 15.6 & 13.2 \\
\hline Banking & & & & 3.2 & 6.6 & 4.8 \\
\hline Other Finance & 3.4 & 26.2 & $\mathrm{NA}$ & 8.3 & 18.3 & 18.6 \\
\hline Other Services & $\underline{\mathrm{NA}}$ & $\underline{\mathrm{NA}}$ & $\underline{\mathrm{NA}}$ & 1.3 & 1.6 & 7.7 \\
\hline \multicolumn{7}{|l|}{ SERVICES } \\
\hline BROADLY DEFINED & 54.5 & 44.3 & 38.9 & 35.7 & 48.2 & 49.0 \\
\hline \multirow[t]{3}{*}{ TOTAL, ALL INDUSTRIES } & 100.0 & 100.0 & 100.0 & 100.0 & 100.0 & 100,0 \\
\hline & \multicolumn{6}{|c|}{ U.S. DIRECT INVESTMENT ABROAD } \\
\hline & 1950 & 1957 & $\underline{1966}$ & 1977 & $\underline{1982}$ & $\underline{1990}$ \\
\hline Agric, Forest, Fish, Mining & 14.6 & 12.0 & 8.7 & 4.8 & 2.7 & 1.6 \\
\hline Petroleum & $28.9^{a}$ & $25.8^{c}$ & 21.2 & 13.4 & 19.1 & 12.2 \\
\hline Manufacturing & 32.6 & 31.7 & 41.9 & 45.7 & 40.1 & 45.4 \\
\hline GOODS PRODUCTION & $\overline{76.2}$ & $69.5^{c}$ & 71.8 & 63.9 & 61.9 & 59.2 \\
\hline \multicolumn{7}{|l|}{$\begin{array}{l}\text { Transp., comnunication, } \\
\text { public utilities }\end{array}$} \\
\hline Wholesale trade & $\begin{array}{r}12.2 \\
4.6\end{array}$ & 8.5 & $\begin{array}{l}4.6 \\
6.9\end{array}$ & $\begin{array}{r}1.6 \\
10 \\
3\end{array}$ & 1.1 & $\begin{array}{l}1.8 \\
1.9\end{array}$ \\
\hline Petroleum trade \& services & NA & 10.0 & 6.9 & 7.2 & 8.7 & $\begin{array}{r}11.2 \\
3.9\end{array}$ \\
\hline Banking & 40 & 0.5 & 0.6 & 3.2 & 5.0 & 5.8 \\
\hline Other Finance & & 3.7 & 8.9 & 15.6 & 8.6 & 26.7 \\
\hline Other Services & 1.7 & 1.2 & 2,4 & 2.8 & 2.2 & 2.9 \\
\hline \multicolumn{7}{|l|}{ SERVICES } \\
\hline BROADLY DEFINED & 23.8 & 30.5 & 28.2 & 36.1 & 38.1 & 40.8 \\
\hline TOTAL, ALL INDUSTRIES & 100.0 & 100.0 & 100.0 & 100.0 & 100.0 & 100.0 \\
\hline
\end{tabular}

Total petroleun including trade and services

bincluding agriculture and mining; excluding petroleum trade and services cIncluding petroleum extraction and refining, but not trade and services. Figures comparable to 1950 are 35.8 and 79.5 . 
consistent trend since 1974 has been a steady growth in investment in service industries, although they were still below 10 per cent of the total in 1990.

If we compare the trends in the distribution of FDI in the U.S. with those of US FDI, we can see several contrasts. One strong contrast is between goods and services, with a large shift toward services in U.S. direct investment and a corresponding decline in the role of goods industries, particularly petroleum. Transportation and public utilities almost vanished from FDI in both directions, although recent relaxations in host-country rules against foreign ownership and the desire for capital investment and modernization may restore some of the past role of these industries in outward U.S. FDI. The major shift in U.S. outward direct investment was the growth in the finance sector, from about 4 per cent in the 1950 s to over 30 per cent in 1990, from far below the share in foreign direct investment in the U.S. to well above the foreign share. The data suggest that U.S. financial firms must have gained in some respect on their foreign rivals over these 30 years.

A different view of the distribution of foreign-owned firms' activity in the U.S., perhaps without some of the possible distortions of the investment position data, is given by the distribution of assets. Assets do have their own defects as an activity measure, giving greater weight to industries with high ratios of capital, including financial capital, to labor than measures of output or comprehensive input measures. They will, therefore, give a high weight to affiliates in finance, even when banking is omitted. In addition, the 
financial assets are much more likely to be outside the U.S. than fixed assets or labor. An advantage of the asset data is that they are available as far back as 1959 and thus give a view of the whole 30 years since then.

The most striking change in the distribution of foreign affiliate assets is the enormous shift from goods industries to service industries, broadly defined to include trade and finance, as well as other services (Table 10). Goods industries accounted for over three quarters of foreign affiliates' assets in 1959 , and only a third in 1987 . The sharpest fall was in the share of the petroleum industry, followed by that in manufacturing. The corresponding increase was not spread over service industries, but was concentrated in finance, although some other service sectors did grow.

This shift in industry composition partly confirms that shown by the data on investment position (Table 9) but the changes in the asset distribution were far larger and show a much larger finance sector, even though the investment position data include banking.

Orr's (1991) estimate of Japanese automobile production assets that were involved in manufacturing, but listed under wholesale trade in the Department of Commerce data, discussed earlier, would roughly double the share of that industry in the total. The share would still be one of the lowest in our list.

A measure of labor input is provided by employment in foreignowned affiliates. Unfortunately, the employment data cover only the second 
Table 10

Industry Distribution of Assets of Foreign-Owned Firms in the United States $1959-1987$

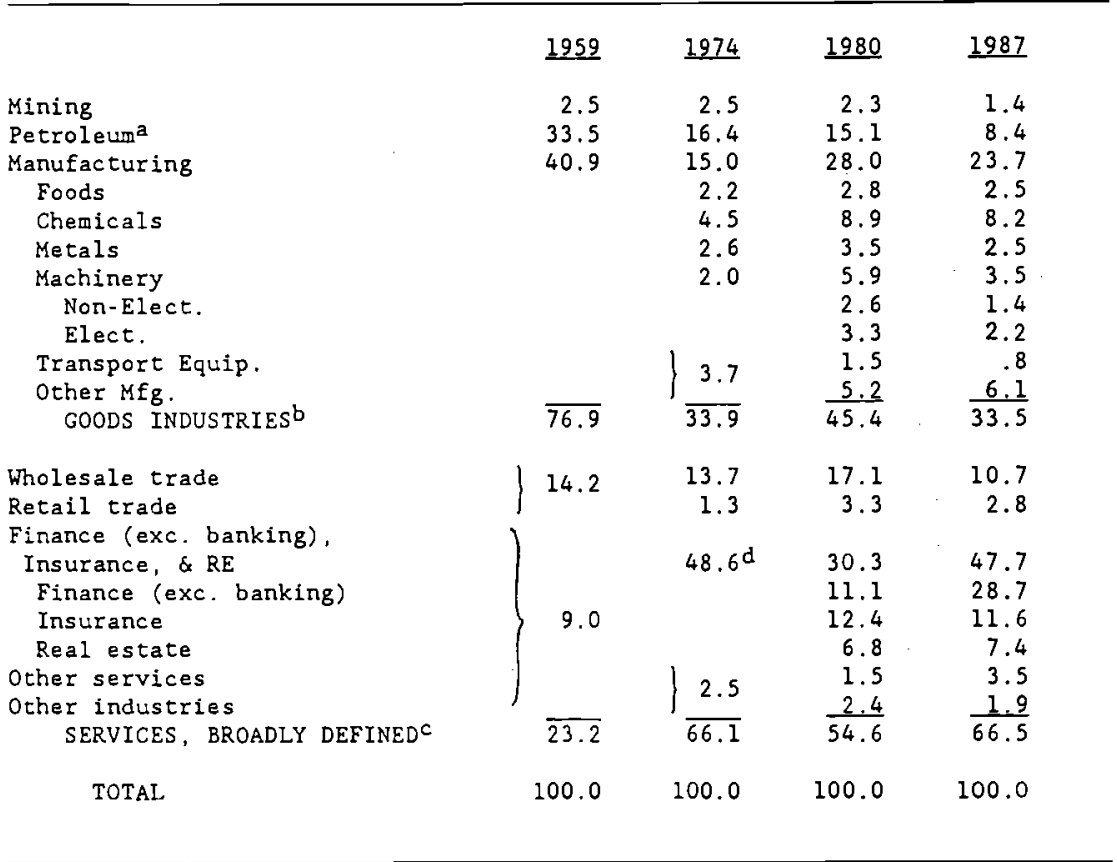

a Includes petroleum trade and services, a little under 20 per cent of the petroleum total in 1974.

bMining, Petroleum, including petroleum trade and services, and Manufacturing.

CIncludes Agriculture; Forestry, and fishing; Transportation, communication and public utilities (over 40 per cent of the total in 1974), Construction, Hotels and lodging places, and Other services.

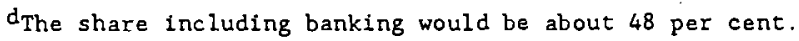

Source: Appendix Table 14. 
half of the period spanned by the data on assets and the direct investment position.

The employment data confirm the shift out of goods production and into service production after the mid-1970s, as well as the particularly large decline in employment in petroleum (Table 11). The rising fields for foreign firms, according to the employment data, were retail trade and other services. However, the employment data do not show the rise in importance of nonbank finance indicated by the investment and assets data.

A comparison of the industry distribution of employment in foreignowned affiliates with that of U.S. firms as a group shows a much slower shift from manufacturing on the part of the foreign firms, but much more of a decline in petroleum, which includes some refining operations. The comparison also points up the much heavier concentration of foreign firms' employment in manufacturing and in goods production in general, more than twice the U.S. proportion by the end of the period. One can read this comparison as a sign of declining comparative advantage of U.S. companies in manufacturing, although not necessarily of the U.S. as a production location, since the foreign firms were choosing the U.S. as a manufacturing location. However, as we have shown elsewhere (Lipsey and Kravis, 1987; Blomström and Lipsey, 1989; and Kravis and Lipsey, 1992), there is no sign of any such decline in competitiveness of U.S. manufacturing firms in world export markets. The rising share of foreign firms in U.S. manufacturing may 
Table 11

Industry Distribution of Non-agricultural Employment:

Foreign Affiliates in the U.S. and All U.S. Firms

Per Cent

\begin{tabular}{|c|c|c|c|c|c|c|}
\hline & \multicolumn{3}{|c|}{ FOREIGN AFFILIATES } & \multicolumn{3}{|c|}{ ALL U.S. FIRMS } \\
\hline & $\underline{1974}$ & 1982 & $\underline{1989}$ & 1974 & 1982 & 1989 \\
\hline Mining & 2.2 & 1.7 & 1.0 & 1.1 & 1.5 & .8 \\
\hline Petroleum & 9.0 & 5.0 & 3.1 & .3 & .3 & .2 \\
\hline Manufacturing & 52.5 & 51.0 & 48.0 & 31.0 & 25.2 & 21.3 \\
\hline Foods & 7.2 & 5.2 & 5.5 & 2.7 & 2.2 & 1.8 \\
\hline Chemicals & 11.0 & 16.0 & 10.0 & 1.7 & 1.5 & 1.2 \\
\hline Metals & 8.4 & 4.2 & 6.3 & 4.3 & 3.2 & 2.4 \\
\hline Mach. exc. elect. & 4.1 & 5.4 & 5.5 & 3.4 & 3.0 & 2.4 \\
\hline Elect. mach. \& equip. & 5.3 & 6.3 & 6.1 & 3.1 & 2.7 & 1.9 \\
\hline Transp. equip. & NA & 2.9 & 1.4 & 2.9 & 2.4 & 2.3 \\
\hline other mfg. & 16.6 & 10.9 & $\underline{13.2}$ & 13.0 & 10.2 & 9.3 \\
\hline GOODS PRODUCTION & 62.9 & 56.9 & 52.1 & 32.4 & 27.0 & 22.4 \\
\hline Public util. \& transp. & 4.3 & 2.3 & 4.2 & 7.4 & 6.9 & 6.2 \\
\hline Construction & .8 & 2.1 & 1.7 & 6.3 & 5.3 & 5.7 \\
\hline Wholesale trade & 11.6 & 11.5 & 8.8 & 6.9 & 7.2 & 6.9 \\
\hline Retail trade & 11.5 & $16: 3$ & 18.5 & 19.6 & 20.6 & 21.6 \\
\hline Finance, incl, banking & & & & 6.5 & 7.2 & 7.4 \\
\hline excl, banking & 4.5 & 5.0 & 5.5 & & & \\
\hline Other services & 3.9 & 5.0 & 9.2 & 21.0 & $\underline{25.8}$ & 30.0 \\
\hline SERVICES, & & & & & & \\
\hline BROADLY DEFINED & 37.1 & 43.1 & 47.9 & 67.6 & 73.0 & 77.6 \\
\hline & & & & & & \\
\hline
\end{tabular}

Source: Appendix Tables 6 and 7. 
reflect mainly the increasing internationalization of the foreign firms.

The other side of this story is the much greater concentration of U.S. employment in services, with the foreign share growing, but still far behind.

A somewhat different picture of the comparative advantages of firms appears if we compare foreign affiliates in the U.S. with U.S. parent companies. In this comparison we are holding constant not only the location of production, but also the multinationality of the firms. Both sets of firms produce in the U.S. and in foreign countries and are probably of similar size, while the total of U.S. firms in Table 11 includes many smaller ones that are less likely to be making a choice of production location.

The distribution of employment by U.S. parents is given in Table 12 . U.S. parents are more concentrated in goods industries than are foreign affiliates, although parent employment, too, has shifted toward service industries. Manufacturing accounts for more of parent employment than of affiliate employment, but the margin has been decreasing, another suggestion that the comparative advantage of U.S. firms relative to foreign firms has been moving away from manufacturing. Among manufacturing industries, chemicals are the industry in which foreign affiliates are much more concentrated than are U.S. parents. Transport equipment is the industry in which U.S. parents are more concentrated than the foreign firms. In neither 
Table 12

Industry Distribution of Employment by Nonbank U.S. Parent Companies, 1977, 1982, and 1989

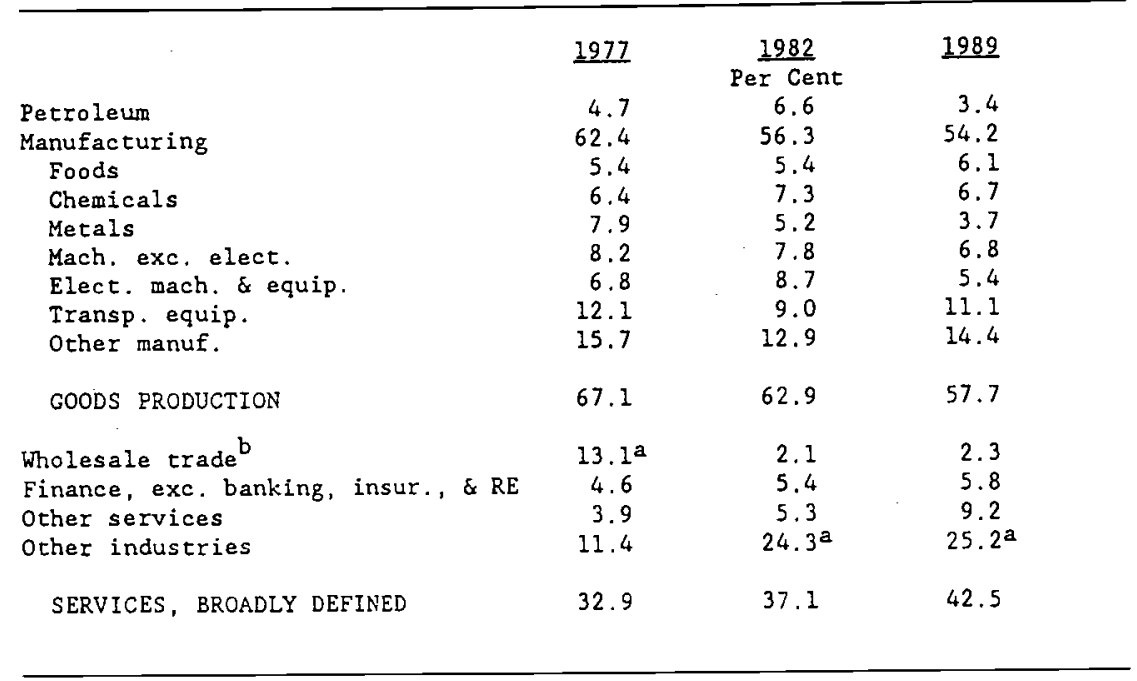

ancludes retail trade

b Including agriculture, mining. except petroleum, construction, transportation, communication, and public utilities.

Source: Appendix Tables 6 and 13 . 
case is there any clear sign of a trend over these 15 years. Outside of manufacturing, U.S. parents and foreign affiliates show the same rising shares of their employment in the narrowly defined service sector.

While labor input by foreign-owned affiliates receives the most attention, we may also wish to observe the distribution of these firms' additions to the physical capital stock of the U.S. Some of the trends observed for labor recur in the capital expenditure data, particularly the steep decline in the shares of the petroleum and mining industries and the rise in the share of the finance sector, all always a much larger part of capital expenditure than of employment. There were also increases in the shares of retail trade in plant and equipment expenditure. This is an industry more important in employment than in capital expenditure (Table 13). In manufacturing there was something of a contrast between the employment and capital expenditure measures: a small decline in the industry's employment share but a rise in its share in capital spending. Those differences suggest more of a move to higher capital intensity among manufacturing affiliates than among those in other industries. Within the finance sector, the major growth was the jump in the share of the real estate industry during the 1970 s. This is always, of course, an extremely capital intensive industry, with a measured capital/labor ratio often inflated 
Table 13

Industry Distribution of Expenditures for Property, Plant, and Equipment by U.S. Affiliates of Foreign Firms, 1974, 1980, and 1987

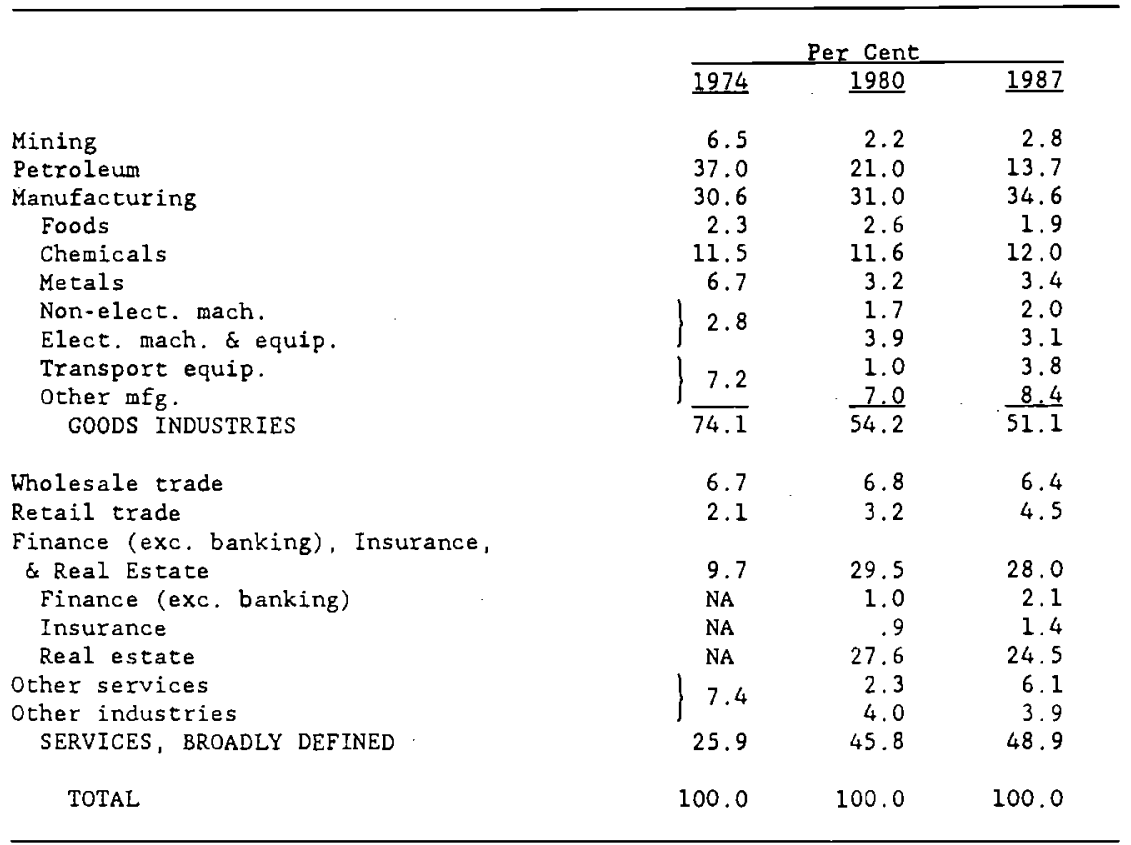

Source: Appendix Table 16 
by the fact that the labor input involved is employed by other service industries, even when it contributes to the sales of the real estate sector.

The closest approach we have to an output measure for foreign-owned affiliates over thirty years is total sales, but we cannot deduct purchased inputs. In the earlier years we cannot even deduct imports, although that would be possible for more recent years.

In 1959, the sales of foreign-owned affiliates in the U.S. were overwhelmingly concentrated in goods industries, particularly petroleum and manufacturing (Table 14). Those two accounted for over 90 per cent of all foreign affiliate sales.

By 1974, almost half the sales were by wholesale trade affiliates, and all goods industries combined accounted for only 40 per cent of total affiliate sales. It is not clear whether there was a great change in the type of goods sold. There may have been only a change in organization, to separate sales from manufacturing activities, or possibly a change in the way the data were collected. Within the goods sector, the changes were smaller, but there was a shift from manufacturing to petroleum and, among manufacturing industry groups, out of foods and into metals.

After 1974 the changes were smaller, mainly the decline in petroleum 
Table 14

Industry Distribution of Sales by U.S. Affiliates of Foreign Firms $1959 \cdot 1987$

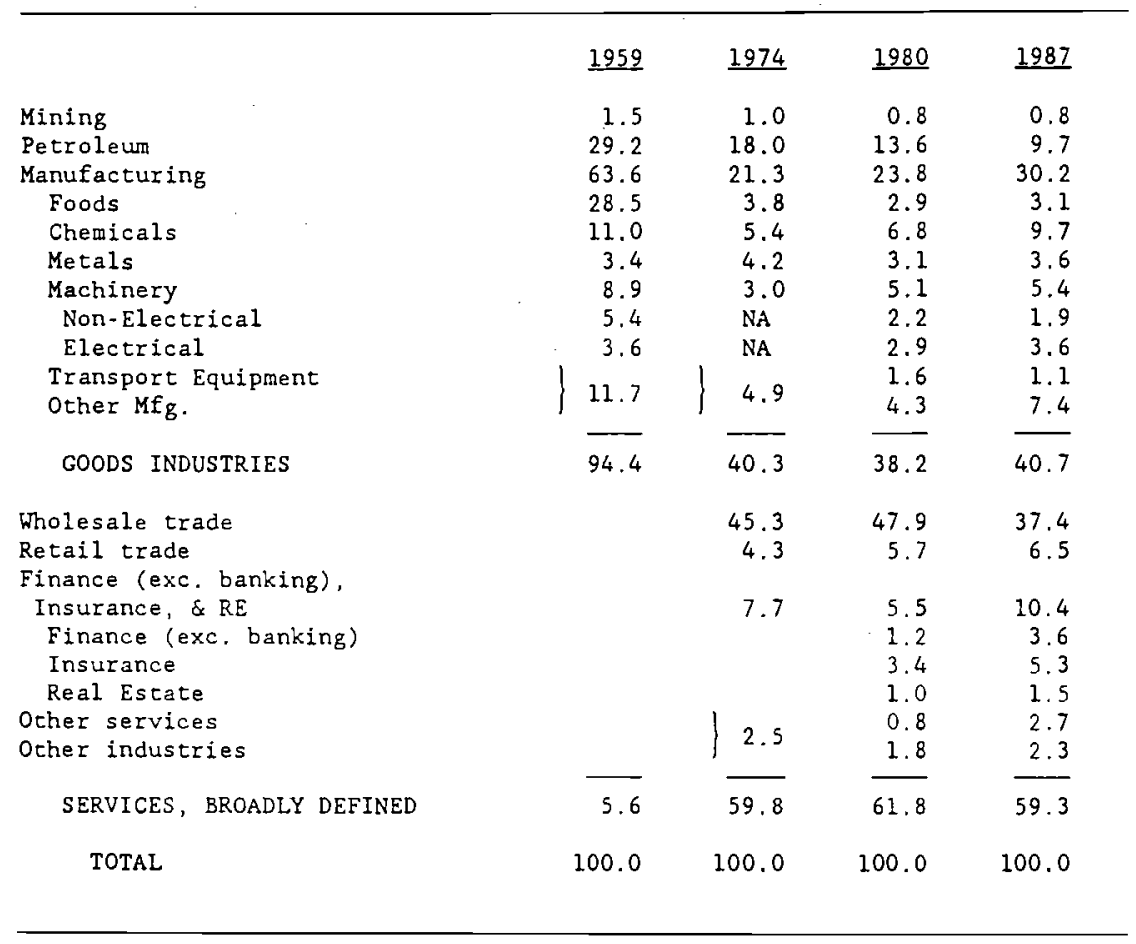

Source: Appendix Table 15 
evident in all the measures, an increase in the importance of manufacturing, in contrast to the employment record, and some shift to retail trade and the finance sector, but no overall move into the broadly defined service sector.

IV.B. The Sources of Foreign Direct Investment in the U.S.

The historical data on the country of origin of direct investment in the U.S. are based on the location of the immediate owner. Only for 1977 and later years are there data on the location of the "ultimate beneficial owner," which can be different for various reasons including the tax treatment of earnings by host countries.

In 1960, foreign direct investment in the United States meant European and Canadian investment, with English-speaking countries alone accounting for

Shares (Per cent) in

Foreign DI in the U.S., 1960

$\begin{array}{lr}\text { Canada } & 28 \\ \text { Europe, total } & \frac{68}{33} \\ \text { UK } & 14 \\ \text { Netherlands } & 11 \\ \text { Switzerland } & 4 \\ \text { Other areas } & \end{array}$

Source: U.S. Dept. of Commerce (1962), Table 1. 
over 60 per cent. The majority of investments were in large enterprises long present in the United States, such as the branch lines of Canadian railroads, Royal Dutch-Shell petroleum interests, and Swiss chemical and pharmaceutical firms. The Commerce Department report for 1960 commented that "A sustained increase in the role of flow of foreign industrial capital to the United States has not yet developed and "The Department of Commerce, and various States, are now developing programs to bring opportunities here to the attention of foreign industrialists and other investors" (U.S. Department of Commerce, 1962, p. 4). There is no indication here of any hostility toward inward investment or any fear of its consequences, but more of an interest in promoting its growth.

The country distribution of investment in 1990 presents some contrasts with the earlier one, but some continuity also, and the later data are available by the country of the ultimate owner rather than only the immediate foreign parent. 


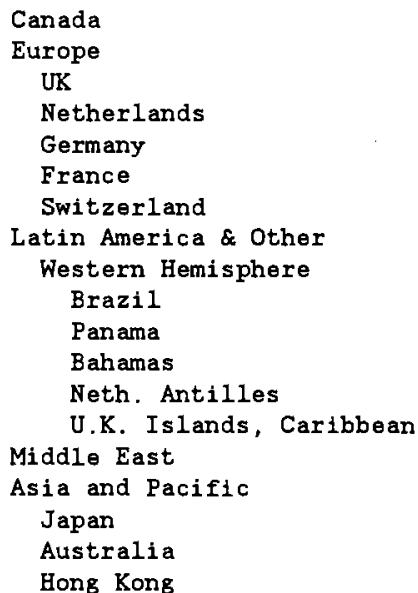

\begin{tabular}{rr} 
Parent & Owner \\
\cline { 2 - 2 } 6.9 & 9.8 \\
63.5 & 59.6 \\
\hline 26.8 & 24.5 \\
15.9 & 11.1 \\
6.9 & 7.9 \\
4.8 & 5.8 \\
4.3 & 4.7 \\
4.9 & \\
\hline .1 & 2.5 \\
.8 & .4 \\
.4 & .1 \\
2.8 & .0 \\
-.8 & .2 \\
1.0 & .2 \\
23.6 & 2.6 \\
\hline 20.7 & 24.5 \\
2.1 & 21.0 \\
.3 & 2.4 \\
\hline 1.6 & .6
\end{tabular}

Source: U.S. Department of Commerce (1991a), Table 18.

The U.K. share declined, but less than might have been expected from the overall decline in the position of the UK in the world economy. The importance of Canada decreased greatly and Germany and France became fairly important sources of investment. The major new source is, of course, Japan, passing the Netherlands in importance and second only to the UK. A country that warranted only a line in the 1960 survey is now the second largest investor of all.

The availability of data by the country of ultimate ownership reveals some interesting contrasts with those by the country of the immediate parent. The latter data are shown to exaggerate the decline in the importance of 
Canada and understate that for the Netherlands, because a change in Canadian tax laws caused some Canadian owners to shift nominal ownership to the Netherlands. Germany and France are shown to be more important as sources of investment than the parent country data indicate. A large part of the direct investment in the U.S. originating in the Middle East, and in Brazil (and other South American countries), is apparently owned through intermediate subsidiaries based in Panama, the Bahamas, and the Netherlands Antilles. "Advantages to UBO's of holding their U.S. investments indirectly through these countries may include minimization of taxes, avoidance of regulatory constraint, and protection of privacy" (Belli, 1981, p. 63). Some examples of Middle Eastern property holdings in the United States with intermediate parents established in the Netherlands Antilles are described in a recent article that also indicates that these intermediaries were shifted to the United States for tax reasons after the passage of the 1986 Tax Reform Act ("Abu Dhabi's Links With a Powerful Law Firm Present Problem for Democrats on BCCI issue," Wall Street Journal, May 20, 1992).

The country distribution of sales in 1959 matched that of the direct investment stock in 1960 fairly well. Companies from Canada accounted for a little over 30 per cent of sales and almost all the rest were from affiliates of companies based in Europe (Table 15). By 1974, only two thirds of sales were from affiliates of Canadian and European firms and that share was approximately the same in 1987 . The very large share of the Netherlands in 
Table 15

Distribution by Country of Ownership of

Sales by All Foreign-Owned Affiliates and Foreign-Owned

Manufacturing Affiliates in the U.S.

$1959-1987$

\begin{tabular}{|c|c|c|c|c|}
\hline & $\underline{1959}$ & $\underline{1974}$ & 1980 & 1987 \\
\hline & \multicolumn{4}{|c|}{ All Affiliaces } \\
\hline Canada & 31.2 & 10.9 & 8.6 & 12.0 \\
\hline Europe & 68.0 & 54.7 & 62.9 & 52.8 \\
\hline UK & 17.9 & 18.5 & 22.9 & 17.6 \\
\hline Netherlands & 36.2 & 11.6 & 9.4 & 7.0 \\
\hline France & 1.2 & 8.7 & 9.9 & 5.9 \\
\hline Germany & 0.6 & 6.0 & 11.1 & 10.0 . \\
\hline Other Europe & 12.1 & 9.9 & 9.6 & 12.3 \\
\hline Japan & 0 & 27.3 & 20.4 & 25.1 \\
\hline \multirow[t]{2}{*}{ TOTAL } & 100.0 & 100.0 & 100.0 & 100.0 \\
\hline & \multicolumn{4}{|c|}{ Manufacturing Affiliates } \\
\hline Canada & 40.2 & 18.8 & 16.0 & 19.4 \\
\hline Europe & 58.9 & 68.1 & 74.8 & 65.3 \\
\hline UK & 24.0 & 24.5 & 18.2 & 21.3 \\
\hline Netherlands & 15.2 & 12.4 & 8.7 & 6.6 \\
\hline France & 1.8 & 6.4 & 12.8 & 7.5 \\
\hline Germany & 0.9 & 8.1 & 19.5 & 13.6 \\
\hline Other Europe & 17.0 & 16.7 & 15.6 & 16.3 \\
\hline Japan & 0 & 4.2 & 4.1 & 6.9 \\
\hline TOTAL & 100.0 & 100.0 & $100: 0$ & 100.0 \\
\hline
\end{tabular}

Source: Appendix Table 15 
1959 , most of which was in the petroleum industry, was greatly reduced by 1974, while affiliates from Japan, largely in wholesale trade, became the largest in terms of sales. After 1974 the pace of change became much slower, the main shifts being a reduction in the Netherlands share and a rise in that of German firms.

The country of origin distribution for manufacturing affiliates showed a little less change than that for all affiliates. The main difference was that Japanese manufacturing affiliates played a much smaller role, remaining behind those from the U.K. and Germany. Also, in manufacturing, the European share remained, in 1987, higher than it had been in 1959. The main shifts in country sources, however, matched those in the total: a large decline for Canada, mainly before 1974, a large and steady decline for Netherlands affiliates, and major increases for those from France, Germany, and Japan.

The distributions of sales by industry and investing country suggest what the directions of comparative advantage were for companies from different countries. For example, cver 70 per cent of U.S. affiliate sales by Netherlands-owned affiliates were in the petroleum industry in 1959, and the share declined, but was still close to half in 1987 , far above the average for other countries (Appendix Table 15). Affiliates from Germany and the Netherlands had exceptionally large shares of their sales in chemicals. Japanese affiliate sales were extremely concentrated in wholesale trade affiliates, because they were, to a large extent, involved in the distribution of 
products exported from Japan. Within manufacturing, however, the Japanese affiliates' sales were particularly large in transport equipment, reflecting the strength of Japanese motor vehicle producers. For the United Kingdom, the specialization in foods was above the average for all foreign firms.

Outside of manufacturing, Canadian firms had disproportionate shares of their sales in insurance, in real estate, and especially in mining. Aside from wholesale trade, finance also accounted for a relatively large share of sales for Japanese firms.

The sales distributions are an indication of the worldwide comparative advantages of firms based in different countries but they may not reflect their advantages in producing in the U.S., since large parts of the affiliate sales, varying widely among firms and countries, originate from production outside the U.S. The employment distributions may reflect more clearly the advantages firms from different countries have in producing in the U.S.

The concentration on chemicals among German firms in 1974 stands out clearly in the fact that 36 per cent of their affiliates' employment in the United States was in that industry, as against an average for all countries of under 11 per cent. The only observable deviations of even close to this magnitude (many entries are missing) from the average distribution for the world are of Japanese firms in wholesale trade and the U.K. firms in retailing.

By 1987 , German affiliates in the U.S., while still more concentrated on chemicals than those of any other country, had diversified, and were then 
of far more importance than average in non-electrical machinery also.

Canadian and French affiliates were much more heavily represented in machinery than were the world's enterprises, on average, and Japanese firms had become exceptionally concentrated in finance (except banking), as well as in wholesale trade.

V. Financial Aspects of Foreign Direct Investment in the United States

For many years, most of the additions to U.S. direct investment abroad have come from the reinvested earnings of U.S. companies already established in foreign countries. Even as early as $1966-76$, almost 60 per cent of the growth in the U.S. outward stock was from reinvestment. The trend has been very different for foreign direct investment in the United States.

Reinvested Earnings of Foreign-Owned Affiliates in The U.S. and Change in Foreign-Direct Investment Position

\begin{tabular}{|c|c|c|c|}
\hline & $\begin{array}{l}\text { Change in } \\
\text { Position }\end{array}$ & $\begin{array}{l}\text { Reinvested } \\
\text { Earnings }\end{array}$ & $\begin{array}{c}\text { Share }(\%) \text { of Reinvested } \\
\text { Earnings }\end{array}$ \\
\hline \multicolumn{4}{|c|}{ ( $\$$ million) } \\
\hline $1950-59$ & 3,314 & 1,528 & 46.1 \\
\hline $1960-69$ & 5,214 & 3,245 & 62.2 \\
\hline $1970-79$ & 42,644 & 14,494 & 34.0 \\
\hline $1980-89$ & 290,717 & 3,146 & 1.1 \\
\hline 1980 & 13,889 & 5,177 & \\
\hline 1981 & 25,668 & 2,945 & 11.5 \\
\hline 1982 & 15,963 & $-2,379$ & -14.9 \\
\hline 1983 & 12,384 & 89 & .7 \\
\hline 1984 & 27,522 & 2,896 & 10.5 \\
\hline 1985 & 20,032 & $-1,378$ & -6.8 \\
\hline 1986 & 35,799 & $-2,293$ & -6.4 \\
\hline $1987^{\mathrm{a}}$ & $51,374^{a}$ & 1,481 & 2.9 \\
\hline $1987^{b}$ & & -883 & -1.7 \\
\hline 1988 & 51,360 & 2,816 & 5.5 \\
\hline 1989 & 59,009 & $-3,844$ & -6.5 \\
\hline 1990 & 29,972 & $-14,008$ & -46.7 \\
\hline
\end{tabular}


Almost half of the growth in the foreign position in the U.S. in the 1950 s, and over 60 per cent in the 1960 s, was financed by reinvested earnings. In the 1970s, however, although reinvested earnings grew rapidly, to over four times the level in the 1960 s, they financed only a third of the growth in the stock, as equity and intercompany account inflows grew to eight times their level of the 1960 s.

The 1980 s were again a contrast to all the earlier periods. Equity and intercompany flows, particularly the former, grew explosively to over twelve times the 1970s level. At the same time, reinvested earnings almost disappeared, falling from $\$ 14$ billion in the 1970 s to about $\$ 3$ billion in the 1980s. In half the years of the 1980 s the reinvested earnings were negative, a cumulative total of $\$ 5$ billion if 1990 is added in. Thus, while U.S. direct investment abroad seems to have entered an era of mature self-financing, with few new firms entering the list of overseas investors, foreign direct investment in the U.S. in the 1980 s went through a period of wild growth, financed by inflows of new money.

The rapid growth of foreign direct investment in recent years has consisted mainly of acquisitions of existing U.S. firms, rather than the establishment of new firms. Comprehensive data from the U.S. Department of Commerce exist only for recent years, but they do show a continued move in this direction. In 1984-87, over 80 per cent of inflows of foreign direct investment were for acquisitions. High as that was, the proportions for 1988- 
90 surpassed them, averaging close to 90 per cent. The acquisition share was even higher in manufacturing, usually over 95 per cent during these years. The only industry in which the establishment of new enterprises predominated was real estate, where 90 per cent of investment flow in 1984-86 and 71 per cent in 1987-90 consisted of the establishment of new enterprises. Even in this case there was a trend toward acquisitions.

Another indication that the investment rush of the last decade has been very different from earlier foreign direct investment in the United States is provided by the collapse in the apparent profitability of such investment.

\author{
Income as Per Cent \\ of FDI Position
}

$\begin{array}{ll}1950-59 & 7.4 \\ 1960-69 & 6.9 \\ 1970-79 & 9.0 \\ 1980-84 & 5.6 \\ 1985-87 & 2.9 \\ 1988-90 & 2.5\end{array}$

Source: U.S. Department of Commerce (1984) and (1991b) and earlier issues.

While there are often good reasons to doubt published data on the profits of segments of enterprises, which is what these affiliates all are, the 
decline looks too large and too sudden to represent only a sudden rise in tax avoidance. The very newness of the recent investments may explain some of the decline. However, the predominance of acquisitions among recent foreign investments means that these are generally going concerns rather than startups, and on that ground alone one might expect a more rapid attainment of normal profit rates.

The data for major industry groups show that the decline in profitability was quite general, but it was much more severe in some groups than in others.

\begin{tabular}{lcccc} 
& \multicolumn{4}{c}{ Income as Per Cent of FDI Position } \\
\cline { 2 - 5 } & Petroleum & Manufacturing & Finance ${ }^{2}$ & Other \\
$1950-59$ & 13.0 & 6.9 & 6.6 & 4.2 \\
$1960-69$ & 10.5 & 7.8 & 4.4 & 4.1 \\
$1970-79$ & 12.6 & 7.5 & 10.5 & 7.4 \\
$1985-87$ & 4.8 & 2.3 & 3.8 & 1.9 \\
$1988-90$ & 7.2 & 4.2 & .6 & -.3 \\
& \multicolumn{4}{c}{} \\
& a Finance, Insurance, and Real Estate
\end{tabular}

In petroleum and manufacturing the very sharp declines to the 1985-87 levels were partially reversed in 1988-90. But equally sharp declines in finance and other industries (mining, wholesale and retail trade, and other industries) were followed in $1988-90$ by even larger declines in profitability, to the point where 
it reached zero or even below.

The geographical breakdown points up the relative stability of the

\begin{tabular}{|c|c|c|c|c|}
\hline \multirow[b]{2}{*}{ Canada } & \multicolumn{2}{|c|}{ Europe } & \multirow[b]{2}{*}{ Neth } & \multirow[b]{2}{*}{ Japan } \\
\hline & Total & U.K. & & \\
\hline$\overline{7.3}$ & 7.6 & 6.6 & $\overline{14.5}$ & NA \\
\hline 5.1 & 7.4 & 6.6 & 10.1 & 12.6 \\
\hline 6.7 & 9.1 & 8.7 & 11.8 & 13.4 \\
\hline .9 & 4.2 & 5.1 & 5.2 & 4.3 \\
\hline-.3 & 3.6 & 6.1 & 2.5 & 1.0 \\
\hline
\end{tabular}

profitability of U.K. investment and levels of profits in the last period for Europe that were far above those of Canada and Japan. European investment was more concentrated in manufacturing than those of Canada and Japan, the latter heavily invested in real estate and banking. But this broad industry breakdown does not tell the whole story; while most areas' manufacturing affiliates remained profitable in the late 1980s, Japan's made losses in both of the last two periods. Japan was also the country whose investment in the U.S. had accelerated most rapidly in the late 1980 s, a hint of a possible connection between the rate of growth of investment and its profitability. Reports in the press suggest that the declining profitability of Japanese direct investment in the U.S. reported in the official data is not a mirage (for example, "How 
Japan Got Burned in the U.S.A., " Fortune, June 15, 1992). A summary of a survey of Japanese-owned U.S. affiliates by a Japanese newspaper stated that "... $80 \%$ of the 264 units weren't returning profits to parent companies and $63 \%$ cited earnings as their biggest concern" "Japanese Wary on U.S. Operations," Wall Street Journal, June 9, 1992.

An examination of the low profitability of foreign affiliates in the U.S. relative to other U.S. firms, based on tax data for the late 1980s (Grubert, Goodspeed, and Swenson, 1991), attributed half of the differential to characteristics of the affiliates and of the period. The affiliate characteristics were the revaluation of target firm assets following acquisitions and the immaturity of the affiliates. Both were. related to the headlong acquisition rate of that period. The main relevant characteristic of the period was the decline in the exchange value of the U.S. dollar.

Some part of the rest of the differential was attributed to income shifting by foreign firms to minimize taxes. That shifting was presumably responsible for the fact that the proportion of affiliates with zero profits was higher than the proportion among domestic firms. The part of the profit differential attributable to income shifting is, in a sense, illusory. In fact, it may represent an incentive for investment in the U.S. However, the sharp 
decline in the direct investment inflow, particularly of equity capital, in 1991, to less than half the 1990 level, reinforces the picture of low and declining profits (U.S. Dept. of Commerce, 1992, Table M).

\section{Summary}

The major development in foreign direct investment in the United States over the past thirty years has been its enormous growth. That is the case whether one considers the absolute values or the shares of the world's direct investment flows and whether one considers book or market valuations. The United States, which had accounted for a greatly disproportionate share of the world's direct investment outflows in the 1960s, far above the U.S. share in the world's income or output even at its peak in 1950, by the 1980 s was accounting for almost half of the world's direct investment inflows. That share was even more disproportionate than the earlier outward share, given the reduced importance of the United States in the world economy.

One consequence of this huge inward flow is that the United States has become almost as much of a host to foreign companies as other countries are to U.S. firms. Foreign direct investment in the U.S., formerly a quarter or even less of U.S. direct investment abroad, is now, even by current cost or 
market valuations, three quarters as large.

The rapid growth of foreign direct investment in the U.S. has left foreign firms still controlling only a small part of total assets of U.S. firms and employing less than 5 per cent of the U.S. labor force. However, the shares have become much more significant in manufacturing, quadrupling in the last 15 years and reaching over 10 per cent of employment. The most notable share of employment has been in chemicals, over 40 per cent in 1989. But the industrial composition of foreign direct investment in manufacturing has been relatively stable; chemicals was the U.S. industry most heavily penetrated by foreign firms in 1974 , and as far back as 1900 , as well as at present. If we rank industries by degree of foreign control in 1974, no industry moved more than one rank by 1989 except electrical machinery, now the second highest at over 15 per cent. The foreign, particularly German, role in chemicals, has a very long history. The level of German activity was high even before World War I and has remained high even though it was reduced twice by confiscations of alien property during the two world wars.

Another measure of the foreign role, the share in plant and equipment expenditure, shows an even higher share - over half - in chemicals, but a much lower one in electrical machinery. The foreign operations may be 
entering relatively capital-intensive sectors of the chemical industry and relatively labor-intensive sectors of the electrical machinery industry.

The trends in the distribution of foreign firms' activity among broad sectors of the economy look different by different measures. The direct investment position data show a large rise in the share of goods industries and then, after 1974, a shift back to services, leaving the goods share a little higher in 1990 than in 1950 and the service share a little lower. In the three decades between 1960 and 1990, however, there was some shift towards services. Data on total assets of foreign-owned firms show a much steadier and stronger shift from goods industries to service industries mainly financial services. The time series on sales suggest a very large shift toward services between 1959 and 1974, but little change since then, while the shorter time series on employment indicate a substantial shift out of goods and into services between 1974 and 1989 , despite the relatively small role they give to financial services. Another short series, on plant and equipment investment, also points to a shift in the direction of service activities by foreign firms, with real estate the major factor here.

Foreign-owned affiliates have continued to import more relative to their exports than U.S. companies in general, but the trend appears to be 
toward foreign affiliates becoming more like other U.S. firms in this respect. The foreign affiliates are quite sensitive to exchange rate changes in adjusting the balance of exports and imports, but not more so than U.S. firms as a group.

Perhaps the most publicized change in inward direct investment in recent years has been its source. Japan, hardly mentioned in the 1960 discussion, now accounts for 20 per cent of the stock of foreign direct investment in the U.S., second only to the British share. Canadian investment has shrunk in importance. But aside from these two, there are many elements of continuity. The U.K. remains the largest investor, as it was in 1960, and for many years before that. The Netherlands is next (after Japan), and the following three are Germany, France, and Switzerland, as in 1960, although the order among them has changed and Germany is now the leader among the three.

Data on shares of affiliate sales give a much larger role to Japan, because of the importance of Japanese wholesale trade affiliates, and they give a comparatively small position to affiliates from the Netherlands. Within manufacturing, however, U.K. affiliates remain the largest single group, and affiliates from the two English speaking countries account for over a third of 
total sales.

One of the largest changes in foreign direct investment in recent years has been in its financing. Whereas half or more of increases in investment in the 1950s and 1960s were financed from retained earnings, the proportion dropped almost to zero in the 1980 s. The pace of new investment was too great to be financed by reinvested earnings in any case, consisting to a large and increasing extent of new entries to the U.S. market through takeovers of existing U.S. firms, but in addition, earnings fell and reinvested earnings were negative in many years during the 1980 s. To some extent the poor earnings reflected the deep recession of the early 1980 s, and that of 1990 also, but one may suspect that poor choices of investment targets, high prices paid for existing companies, and the willingness of foreign firms to pay heavily for access to U.S. markets may all have played a role. The steep decline in rates of return during the 1980s also points in the same direction, although affiliates from the Netherlands and Canada, two traditional sources of foreign investment, also suffered sharp reductions in profitability. 


\section{$\underline{\text { References }}$}

Belli, R. David (1981), "U.S. Business Enterprises Acquired or Established by Foreign Direct Investors in 1980." Survey of Current Business, Vol. 61, No. 8, August.

Blomström, Magnus, and Robert E. Lipsey (1989), "The Export Performance of U.S. and Swedish Multinationals, " Review of Income and Wealth, Series 35, No.3, September.

Di Lullo, Anthony J. (1991), "U.S. International Transactions, Third Quarter 1991," Survey of Current Business, Vol. 71, No. 12, December.

Eisner, Robert, and Paul J. Pieper (1990), "The World's Greatest Debtor Nation?" in The North American Review of Economics and Finance, Vol. 1, No. 1, Greenwich, CT., JAI Press

Federal Reserve Board (1992), Flows of Funds Accounts: Financial Assets and Liabilities, Annual Revisions, Washington, D.C., Board of Governors of the Federal Reserve System.

Goldsmith, Raymond W., and Robert E. Lipsey (1963), Studies in the National Balance Sheet of the United States, Vol. I, Princeton University Press for the NBER. 
Grubert, Harry, Timothy Goodspeed, and Debrah Swenson (1991), "Explaining the Low Taxable Income of Foreign-Controlled Companies in the United States." Unpublished paper, November. Kravis, Irving B., and Robert E. Lipsey (1992), "Sources of Competitiveness of the U.S. and its Multinational Firms." Review of Economics and Statistics, Vol. LXXIV, No. 2, May.

Landefeld, J. Steven, and Ann M. Lawson (1991), "Valuation of the U.S. Net International Investment Position," Survey of Current Business, Vol. 71, No. 5, May.

Lipsey, Robert E. (1988), "Changing Patterns of International Investment in and by the United States," in Martin Feldstein, Ed., The United States in the World Economy, Chicago and London, University of Chicago Press.

(1989), "The Internationalization of Production, " NBER Working Paper 2923 (April). (1991), "Foreign Direct Investment in the United States and U.S. Trade," Annals of the American Academy of Political and Social Science, No. 516, July, pp. 76-90. 
Lipsey, Robert E., and Irving B. Kravis (1987), "The Competitiveness and Comparative Advantage of U.S. Multinationals, 1957-1984, " Banca Nazionale del Lavoro Quarterly Review, No. 161, June.

Lowe, Jeffrey H. (1990), "Gross Product of U.S. Affiliate of Foreign Companies, 1977-87, " Survey of Current Business, Vol. 70, No. 6, June.

Musgrave, John (1990), "Fixed Reproducible Tangible Wealth in the United States, 1986-89." Survey of Current Business, Vol. 70, No. 8.

Orr, James (1991), "The Trade Balance Effects of Foreign Direct Investment in U.S. Manufacturing," Federal Reserve Bank of New York Quarterly Review, Volume 16, No. 2, Summer.

Quijano, Alicia M. (1990), "A Guide to BEA Statistics on Foreign Direct Investment in the United States," Survey of Current Business, Vol. 70, No. 2, February.

Scholl, Russell B. (1991), "The International Investment Position of the United States in 1990, "Survey of Current Business, Vol. 71, No. 6, June. 
Seskin, Eugene P., and David F. Sullivan (1988), "Plant and Equipment Expenditures, the Four Quarters of 1988," Survey of Current Business, Vol. 68, No. 6, June.

Ulan, Michael, and William G. Dewald (1989), "The U.S. Net International Investment Position: Misstated and Misunderstood, " in James A. Dorn and William A. Niskanen, Editors, Dollars, Deficits, and Trade, Norwell, MA, Kluwer Academic Publishers for the Cato Institute.

United Nations (1973), Multinational Corporations in World Development, New York, Department of Economic and Social Affairs. (1978), Transnational Corporations in World Development:

A Re-examination, New York, UN Centre on Transnational Corporations. (1983), Transnational Corporations in World Development,

Third Survey, New York, UN Centre on Transnational Corporations. (1985), Trends and Issues in Foreign Direct Investment and

Related Flows, New York, UN Centre on Transnational Corporations. 
(1988), Transnational Corporations in World

Development, Trends and Prospects, New York, UN Centre on Transnational Corporations. (1989), "FDI Flows in the Mid-1980s." The CTC Reporter,

No.27, Spring, New York, UN Centre on Transnational Corporations. (1990a), Monthly Bulletin of Statistics, Vol. XLIV, No. 5,

May. (1990b), 1988 International Trade Statistics

Yearbook. (1991a), Commodity Trade Statistics, 1989, Statistical Papers, Series D, Vol. XXXIX, No. 1-11. (1991b), World Investment Report, 1991, The Triad in

Foreign Direct Investment, New York, UN Centre on Transnational Corporations. (1992), World Investment Report, 1992, Transnational Corporations as Engines of Growth, New York.

U.S. Bureau of the Census (1991), Statistical Abstract of the United States, 1991, Washington, D.C. 
U.S. Department of Commerce (1960), U.S. Business Investments in Foreign Countries, Washington, D.C., Office of Business Economics. (1962), Foreign Business Investments in the

United States, A Supplement to the Survey of Current Business, Washington, D.C., Office of Business Economics. (1976), Foreign Direct Investment in the

United States, Benchmark Survey, 1974, Vol. 2, Report of the Secretary of Commerce to the Congress in Compliance with the Foreign Investment Study Act of 1974, Washington, D.C., U.S. Department of Commerce, April. (1982), Selected Data on U.S. Direct

Investment Abroad, 1950-76, Washington, D.C., Bureau of Economic Analysis. (1983), Foreign Direct Investment in the

United States, 1980, Washington, D.C., Bureau of Economic Analysis. 
Investment in the United States, 1950-79, Washington, D.C., Bureau of Economic Analysis, December. (1985), Foreign Direct Investment in the

United States: Operations of U.S. Affiliates, 1977-80, Washington, D.C., Bureau of Economic Analysis.

(1989), Business Statistics, 1961-1988,

Bureau of Economic Analysis, December. (1990), Foreign Direct Investment in the

United States, 1987 Benchmark Survey, Final Results, Washington, D.C., Bureau of Economic Analysis, August. (1990), Foreign Direct Investment in the

United States: Balance of Payments and Direct Investment Position Estimates, 1980-86, Washington, D.C., Bureau of Economic Analysis, December. (1991a), "Foreign Direct Investment in the

United States: Detail for Historical-Cost Position and Balance of Payments Flows, 1990," Survey of Current Business, Vol. 71, No. 8, August. 
(1991b), "U.S. Direct Investment Abroad:

Detail for Historical-Cost Position and Balance of Payments Flows, 1990," Survey of Current Business, Vol. 71, No. 8, August. (1991c), Foreign Direct Investment in the

United States: Operations of U.S. Affiliates of Foreign Companies,

Preliminary 1989 Estimates, Bureau of Economic Analysis, August. (1991d), Foreign Direct Investment in the

United States: Review and Analysis of Current Developments,

Washington, D.C., Economics and Statistics Administration, Office of the Chief Economist, August. (1991e), Survey of Current Business, Vol.71,

No. 11, November. (1992), Survey of Current Business, Vol. 72,

No. 3, March.

Wilkins, Mira (1989), The History of Foreign Investment in the United States to 1914, Cambridge, Mass., Harvard University Press. 
Appendix Tables

1. U.S., Developed Country, and World Direct Investment Inflows and Outflows, $1967-1990$

2. U.S. Direct Investment Abroad, by Industry of Affiliate

3. Foreign Direct Investment in the U.S., by Industry of Affiliate

4. U.S. Corporation Financial and Fixed Capital Stocks, 1959, 1973, 1977 1989

5. Total Assets of Foreign Affiliates, 1959, 1973, 1977-1989

6. Employment of Nonbank U.S. Affiliates of Foreign Corporations, by Industry of Affiliate, 1974-1989

7. Employment on Private Nonagricultural Payrolls in the U.S., by Industry, $1974-1990$

8. Exports and Imports of Merchandise From and Into the United States and Total Sales by U.S. Manufacturing Affiliates of Foreign Firms, 1974 and 1977 to 1989

9. U.S. Manufacturing Exports

10. U.S. Manufacturing Shipments, by Industry

11. U.S. Manufacturing Plant and Equipment Expenditures, by Industry, 19701989 
12. Property, Plant, and Equipment Expenditures by U.S. Manufacturing Affiliates of Foreign Firms, 1974-1989

13. Employment of Nonbank U.S. Parent Companies, by Industry, 1977, $1982-89$

14. Assets of U.S. Affiliates of Foreign Firms, by Industry and Investing Country, 1959, 1974, 1980, and 1987.

15. Sales of U.S. Affiliates of Foreign Firms, by Industry and Investing Country, 1959, 1974, 1980, and 1987.

16. Expenditures for Property, Plant, and Equipment by U.S. Affiliates of Foreign Firms by Industry and Investing Country 1974, 1980, and 1987.

17. Employment in U.S. Affiliates of Foreign Firms, by Industry and Investing Country 1974, 1980, and 1987. 
Appendix Table 1

U.S., Developed Country, and World Direct Investment Inflows and Outflows, 1967-1990, Annual Averages ( $\$$ million)

\begin{tabular}{|c|c|c|c|c|c|c|}
\hline & \multicolumn{3}{|c|}{ Inflows } & \multicolumn{3}{|c|}{ Outflows } \\
\hline & U.S. & $\begin{array}{l}\text { Developed } \\
\text { Countries }\end{array}$ & World & U.S. & $\begin{array}{l}\text { Developed } \\
\text { Countries }\end{array}$ & World \\
\hline $\begin{array}{c}1960^{a} \\
1965-66^{a, b} \\
1965 \cdot 66^{a}\end{array}$ & $\begin{array}{r}140 \\
72 \\
72\end{array}$ & $\begin{array}{l}2,271 \\
3,215 \\
3,816\end{array}$ & & $\begin{array}{l}1,674 \\
3,564 \\
3,564\end{array}$ & $\begin{array}{l}2,906 \\
5,492 \\
5,564\end{array}$ & \\
\hline $\begin{array}{l}1967-69^{c}, d \\
1967-69^{c} \\
1970-72^{c} \\
1973-75^{c}\end{array}$ & $\begin{array}{r}923 \\
923 \\
926 \\
3,795\end{array}$ & $\begin{array}{r}5,298 \\
5,534 \\
8,902 \\
14,464\end{array}$ & $\begin{array}{l}12,785^{\mathrm{e}} \\
22,560^{\mathrm{e}}\end{array}$ & $\begin{array}{r}5,173 \\
5,173 \\
7,651 \\
11,498\end{array}$ & $\begin{array}{r}8,358 \\
9,101 \\
14.744 \\
26,256\end{array}$ & \\
\hline $\begin{array}{l}1973-75^{f} \\
1975-80^{f}\end{array}$ & $\begin{array}{l}3,400 \\
8,261\end{array}$ & $\begin{array}{l}13,981 \\
23,326\end{array}$ & $\begin{array}{l}18,065 \\
31,492\end{array}$ & $\begin{array}{l}11,573 \\
19,341\end{array}$ & $\begin{array}{l}23,677 \\
40,510\end{array}$ & \\
\hline $\begin{array}{l}1975-808 \\
1981-858\end{array}$ & $\begin{array}{r}7,900 \\
19,090\end{array}$ & $\begin{array}{l}24,600 \\
36,600\end{array}$ & $\begin{array}{l}32.100 \\
48.700\end{array}$ & $\begin{array}{r}17.100 \\
8.600\end{array}$ & $\begin{array}{l}39,800 \\
44,400\end{array}$ & $\begin{array}{l}40,300 \\
45,300\end{array}$ \\
\hline $\begin{array}{l}1980.84^{h} \\
1985.89^{h}\end{array}$ & $\begin{array}{l}14,000 \\
18,000\end{array}$ & & $\begin{array}{r}45,000 \\
100,000\end{array}$ & $\begin{array}{l}19,000 \\
46,000\end{array}$ & & $\begin{array}{r}44,000 \\
105,000\end{array}$ \\
\hline $\begin{array}{l}1970.79^{1} \\
1980-85^{1} \\
1986.90^{i}\end{array}$ & & $\begin{array}{r}17,300 \\
37,100 \\
122,600\end{array}$ & $\begin{array}{r}22,700 \\
49,700 \\
149,200\end{array}$ & 22.760 & 158,600 & 164,300 \\
\hline
\end{tabular}

${ }^{a}$ UN (1973), Table 9

bomparable in coverage to 1960

CUN (1978). Tables III-34 and III-43

dComparable in coverage to $1965-66$

Inflows of developed countries plus developed country outflows to developing countries.

$f_{U N}$ (1983), Annex Tables II.1 and II.2

BUN (1988), Tables V.1 and V-2

$h_{U N}(1991)$, Table 10

i UN (1992) 


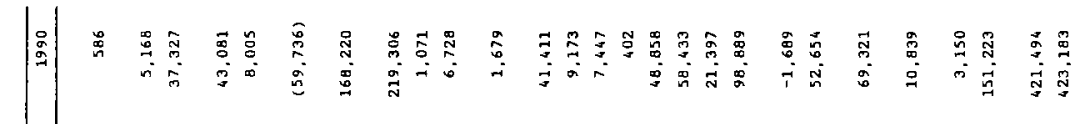

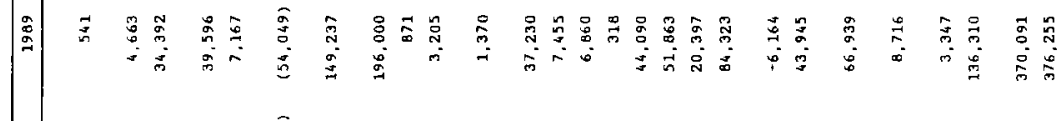

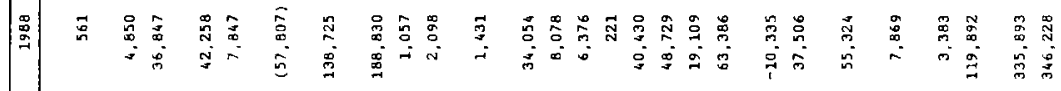

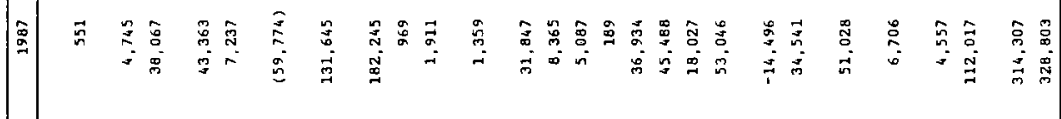

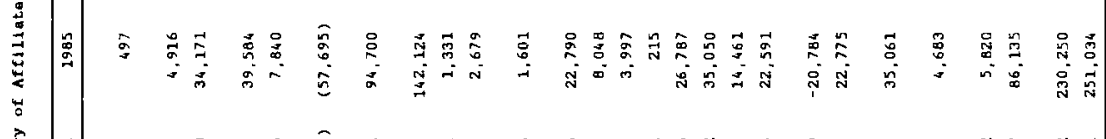

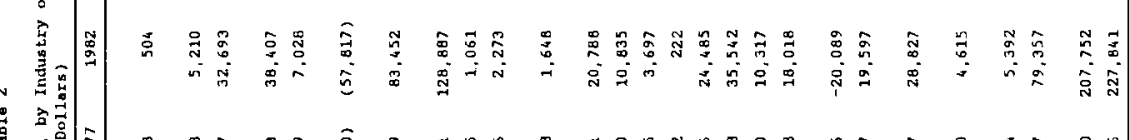

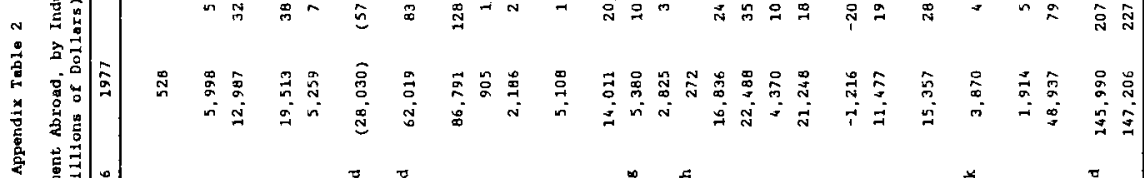

|

J

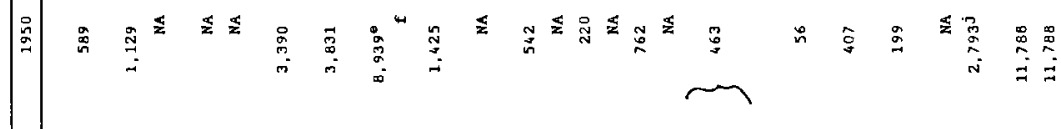

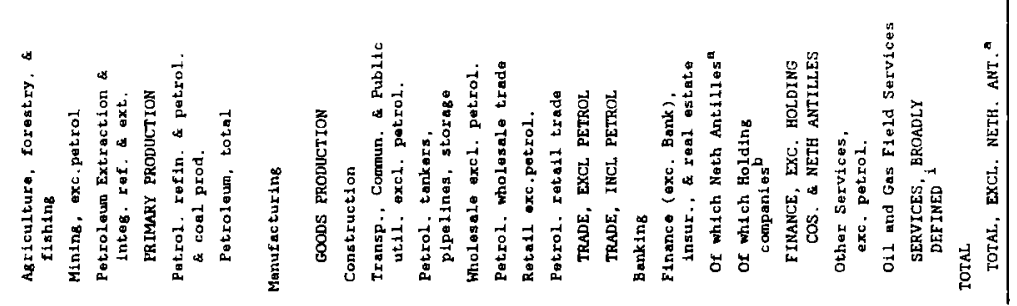




\section{Notes to Appendix Table 2}

a. We omit Netherlands Antilles Finance affiliates after 1977 because they are almost entirely "shell" operations set up for tax reasons to borrow abroad and relend the proceeds to their parents.

b. The operating companies owned by the holding companies are often outside the finance sector.

c. Figures comparable to 1950 are 26,278 for total investment, 9,106 for petroleum, and 8,414 for manufacturing.

d. Figures comparable to 1957 are 54,799 for total investment, 16,222 for petroleum, and 22,078 for manufacturing.

e. Includes all petroleum operations. Corresponding 1957 figure is 20,105 .

f. Included with other services.

g. Includes petroleun retail trade (service stations)

h. Included with petroleum wholesale trade

i. All except goods industries

j. Excludes petroleun trade and services. Corresponding 1957 figure is 5,178

k. Hotels, advertising \& other business services, motion pictures, and all other, including inactive.

Sources: 1950 and 1957: U.S. Dept. of Commerce (1960), Tables 5 and 6, pp. 93 and 94, and U.S. Dept. of Commerce (1982), Table A.

1966: U.S. Dept. of Commerce (1982), Table A, and U.S. Dept. of Commerce (1975), Table A-15. Data are on an "allocated" basis. Affiliates owned indirectly are classified by their country and industry of operation rather than by the country and industry of the primary affiliates that are their intermediate owners. The largest effects are to increase the importance of petroleun wholesale trade and of manufacturing and to decrease the importance of holding companies.

1977: U.S. Dept. of Commerce (1981), Table C, Pp. 10 and 11, and Table I.W 3 .

1982-1990: U.S. Dept. of Commerce (1991b), Table 5 \& Table 18 and earlier articles in the same series. 
Appendix Table 3

Foreign Direct Investrent in the U.S., by Industry of Actiliate (millions of dollags)

\begin{tabular}{|c|c|c|c|c|c|c|c|c|}
\hline & 1950 & 1960 & 1966 & $1974 \mathrm{~A}$ & $1974 \mathrm{~B}$ & 2977 & 1980 & 1982 \\
\hline $\begin{array}{l}\text { Abriculture, forestry, \& } \\
\text { fishing }\end{array}$ & NA & $\mathbf{B}$ & NA & $33^{4}$ & MA & MA & 773 & 1,049 \\
\hline Mining, exc pet $r \square 1$ & NA & Bв & NA & 427 & NA & $\mathrm{MA}_{\mathrm{A}}$ & 1,320 & 1,876 \\
\hline $\begin{array}{l}\text { Eetraleum Extraction } \& \\
\text { integ. rof. } s \text { ext. }\end{array}$ & NA & $\mathrm{MA}$ & NA & $6,153^{b}$ & $\mathrm{NA}$ & $\mathrm{MA}$ & 20,229 & 24,199 \\
\hline PRIMARY FRODUCTICN & NA & NA & NA & 6,613 & $\mathrm{NA}$ & NA & 12.322 & 17,124 \\
\hline $\begin{array}{l}\text { Eotrol. rafin. \& patrol. \& } \\
\text { coal prod. }\end{array}$ & NA. & MA & NA & HA & NA & NA & 39 & 44 \\
\hline Patroloum, total & 405 & 1,238 & 1,740 & $(6,354)$ & 5,614 & 6,573 & $(12,200)$ & $(17,660)$ \\
\hline Manufacturing & 1,138 & 2,611 & 3,789 & 8,242 & 10,387 & 14,030 & 33,011 & 44,065 \\
\hline GOODS FRODUCTION & & & & 14,855 & & & 45,372 & 61,233 \\
\hline MANUF . \& PETROLEUM & 1,543 & 3,849 & 5,529 & 14,596 & 16,001 & 20,603 & 45.211 & \\
\hline Construction & $\mathrm{NA}$ & 8 & $\mathrm{NA}$ & $33^{\mathrm{a}}$ & $\mathrm{NA}$ & NA & 522 & 3,692 \\
\hline $\begin{array}{c}\text { Iransp., Comnun. \& Public } \\
\text { util. exel. petzol. }\end{array}$ & $\mathrm{NA}$ & 408 & NA & 347 & NA & $\mathrm{MA}$ & 774 & 1,379 \\
\hline $\begin{array}{l}\text { Petrol. tankers, pipelines, } \\
\text { storage }\end{array}$ & NA & MA & NA & 232 & NA & NA & 368 & 457 \\
\hline Whalesale axcl. petrol. & $\mathrm{NA}$ & $\mathrm{NA}$ & NA & 4,153 & NA & NA & 11,560 & 18,397 \\
\hline Petrol. wholesale trade & iA & NA & MA & -52 & MA & NA & 962 & 1,909 \\
\hline Retail exe.petral. & iA & NA & $\mathrm{NA}_{\mathrm{A}}$ & 425 & $N_{A}$ & NA & 3,650 & 5,207 \\
\hline TRADE, EXCL PETROL & $784^{\circ}$ & 634 & $\mathrm{KA}$ & 4,578 & $5,613^{c}$ & $8,594^{c}$ & 15,210 & 23,604 \\
\hline $\begin{array}{l}\text { TRADE, INCL PETROL } \\
\text { WHCLESALE }\end{array}$ & MA & HA & $\mathrm{NA}$ & 4,526 & $\mathrm{NA}$ & NA & 16.172 & 25.513 \\
\hline Barixing & $\mathrm{MA}$ & NA & NA & 510 & $N_{A}$ & NA & 4,617 & 7,846 \\
\hline $\begin{array}{l}\text { Finance (oxc. Bank), insur., } \\
\text { \& real astate }\end{array}$ & NA & $\mathrm{HA}$ & NA & 5,686 & NA & NA & 13,530 & 22,607 \\
\hline Of which Holding companies & NA & NA & $\mathrm{NA}$ & 3,807 & NA & NA & 857 & 9,772 \\
\hline FINANCE, EXC. HOLDING COS. & NA & $N_{A}$ & NA & 2,389 & MA & Ns & 17,290 & 27,681 \\
\hline FINANCE, INC, GOLDING COS, & 1.065 & 1,810 & 2,072 & 6,196 & 5,613 & 5,398 & 18,147 & 29,453 \\
\hline Other Services, axc.petrol. & NA & $121^{h}$ & NA & 302 & NA & NA & 1,089 & 1,899 \\
\hline Oil and Gas Fiold Services & NA & MA & NA & 21 & NA & KA & 601 & 1,051 \\
\hline SERVICES, ERCADLY DEFIMEDd & & & & 7,850 & & & 36,817 & 61,672 \\
\hline SERVICES, BROADLY DEF INED ${ }^{\circ}$ & 1,848 & 3,061 & 3,525 & B.,109 & 9,243 & 13,992 & & \\
\hline TOTAL & 3,391 & 6,910 & 9,054 & 26,522 & 25,144 & 34,595 & 83,046 & 224,677 \\
\hline
\end{tabular}


Appendix Table 3 (continued)

Forelgn Direct Investment in the U.S., by Industry of Affiliate (millions of dollars)

\begin{tabular}{|c|c|c|c|c|c|c|c|c|}
\hline & 1983 & 1984 & 1985 & 1986 & 1987 & 1988 & 1989 & 1990 \\
\hline $\begin{array}{l}\text { Asriculcure, forestry, } \\
\text { flobing }\end{array}$ & 1.148 & 1,150 & 1.106 & 1.250 & 1,250 & 1.116 & 1,233 & 1.134 \\
\hline Mining. exc.petrol & 1.928 & 3.920 & 4.039 & 5.080 & 5,591 & 7,440 & B. 821 & 10,310 \\
\hline $\begin{array}{l}\text { Petrolaum Extraction \& } \\
\text { lnteg. ref. \& oxt. }\end{array}$ & 15.385 & 21,913 & 24,305 & 24,225 & 33,151 & 30,806 & 29,362 & 28,493 \\
\hline PRIMARY ERODUCTION & 18,461 & 26,983 & 29,450 & 30,555 & 39.992 & 39,362 & 39,416 & 39.937 \\
\hline $\begin{array}{l}\text { Potrol, refln. patrol. } \\
\text { coal prod. }\end{array}$ & 31 & 28 & 21 & 58 & 687 & 764 & 1,927 & 2,939 \\
\hline Eotroleum, total & $(18.209)$ & $(25,400)$ & $(28.270)$ & $(29,094)$ & $(37,815)$ & $(36.006)$ & $(37,201)$ & $(38.004)$ \\
\hline Manufacturing & 47.665 & 51.802 & 59.584 & 71.963 & 93,865 & 322,582 & 151,820 & 159.998 \\
\hline GOODS PRODUCIION & 66.157 & 78,813 & 89,055 & 102,576 & 134,544 & 162,708 & 193,163 & 202,874 \\
\hline Construction & 3,676 & 4,337 & 4,037 & 3,602 & 1,345 & 1.519 & 2,386 & 2,088 \\
\hline $\begin{array}{l}\text { Iransp. Commun. \& Publle } \\
\text { util, excl, petrol. }\end{array}$ & 1,572 & 1.633 & 1,934 & 2,292 & 3,136 & 3.576 & 6,179 & 6.607 \\
\hline $\begin{array}{l}\text { Eatrol. tankers, pipelines, } \\
\text { storege }\end{array}$ & $587^{i}$ & $538^{4}$ & $501^{1}$ & $534^{i}$ & 609 & 1,007 & 797 & 811 \\
\hline Wholeselo oxcl. petrol. & 21,031 & 24,455 & 29,051 & 33,997 & 37,427 & 43,725 & 46,297 & 52,646 \\
\hline Potrol. wholesale trade & 1,202 & 1,930 & 2,767 & 3,734 & 3,101 & 2.827 & 4,830 & 5,490 \\
\hline Rotail exc. potrol. & 5,482 & 6.764 & 6.822 & 8,923 & 7,972 & 9.865 & 9,013 & 9,350 \\
\hline Eotrol, retail trade & j & j & $j$ & $\mathrm{~J}$ & 5 & 437 & 59 & 71 \\
\hline TRADE, EXCL PETROL & 26,513 & 31.219 & 35,873 & 42,920 & 45,399 & 53,590 & 55,310 & 61,996 \\
\hline $\begin{array}{l}\text { TRADE, INCL PETROL } \\
\text { WHOLESALING }\end{array}$ & 27,715 & 33.149 & 38,640 & 46,654 & $48,505^{i}$ & $56.854^{1}$ & $60,199^{1}$ & $67,557^{1}$ \\
\hline Bankings & 8,697 & 10,326 & 11,377 & 12,394 & 14,354 & 16,906 & 18,638 & 19,089 \\
\hline $\begin{array}{l}\text { Finance (oxc. Bank), insur, } \\
\text { E roal ostate }\end{array}$ & 25.570 & 32,316 & 35.454 & 45.096 & 47.126 & 52,971 & 69.637 & 73,974 \\
\hline Eoiding corpanies & 2.213 & 3,687 & 3,793 & 3,560 & 3,131 & 4.795 & 6,266 & 6,115 \\
\hline FINANCE, EXC. HOLDING COS. & 32,054 & 38.955 & 43,038 & 53,930 & 58.349 & 65,082 & 82.009 & 86,948 \\
\hline FINANCE, INC, HOLDING COS, & 34,267 & 42.642 & 46.831 & 57,490 & 61,480 & 69.877 & 88.275 & 93,063 \\
\hline Otber Sorvices, exc.petrol. & 2.082 & 2.479 & 2,943 & 6,724 & 13,514 & 19,048 & 22.536 & 30,536 \\
\hline oil and gas flold services & 1,005 & 990 & 676 & 542 & 262 & 166 & 227 & 200 \\
\hline SERVICES, BROADLY DEFINEDd & 68,691 & 82,083 & 91,767 & 114,278 & 125,719 & 147.251 & 174,334 & 194,746 \\
\hline TOTAL. & 137,061 & 164.583 & 184.615 & 220.414 & 263,394 & 314,754 & 373,763 & 403,735 \\
\hline
\end{tabular}


Sources: $1950,1960,1966,1974$ B, 1977: U.S. Department of Commerce (1984), Table 1.

Trade and finance data for 1950 and 1960 are from U.S. Dept. of Commerce (1962), Table 1, Pg. 34 .

1974A: U.S. Department of Commerce 1976, Tables 2 and A-4. These data have been revised in the source listed for 1977 and earlier years, but we used this source for its superior detail.

1980-90: U.S. Department of Commerce (1991b) and earlier articles in the same series.

Notes:

a. Investment in unincorporated affiliates in agriculture and construction is combined in the source. We assumed that half was in agriculture, half in construction.

b. Includes petroleum refining and petroleum and coal products

c. Trade, services, construction, transportation, communication, and public utilities.

d. Total investment minus goods production.

e, Same, but excluding petroleum trade and services.

f. Including all petroleum; excluding agriculture, forestry, fishing, and mining

g. Included in Other services.

$h$. Including agriculture and construction.

i. Includes petroleum retailing.

j. Included in petroleum tankers, pipelines, storage. 


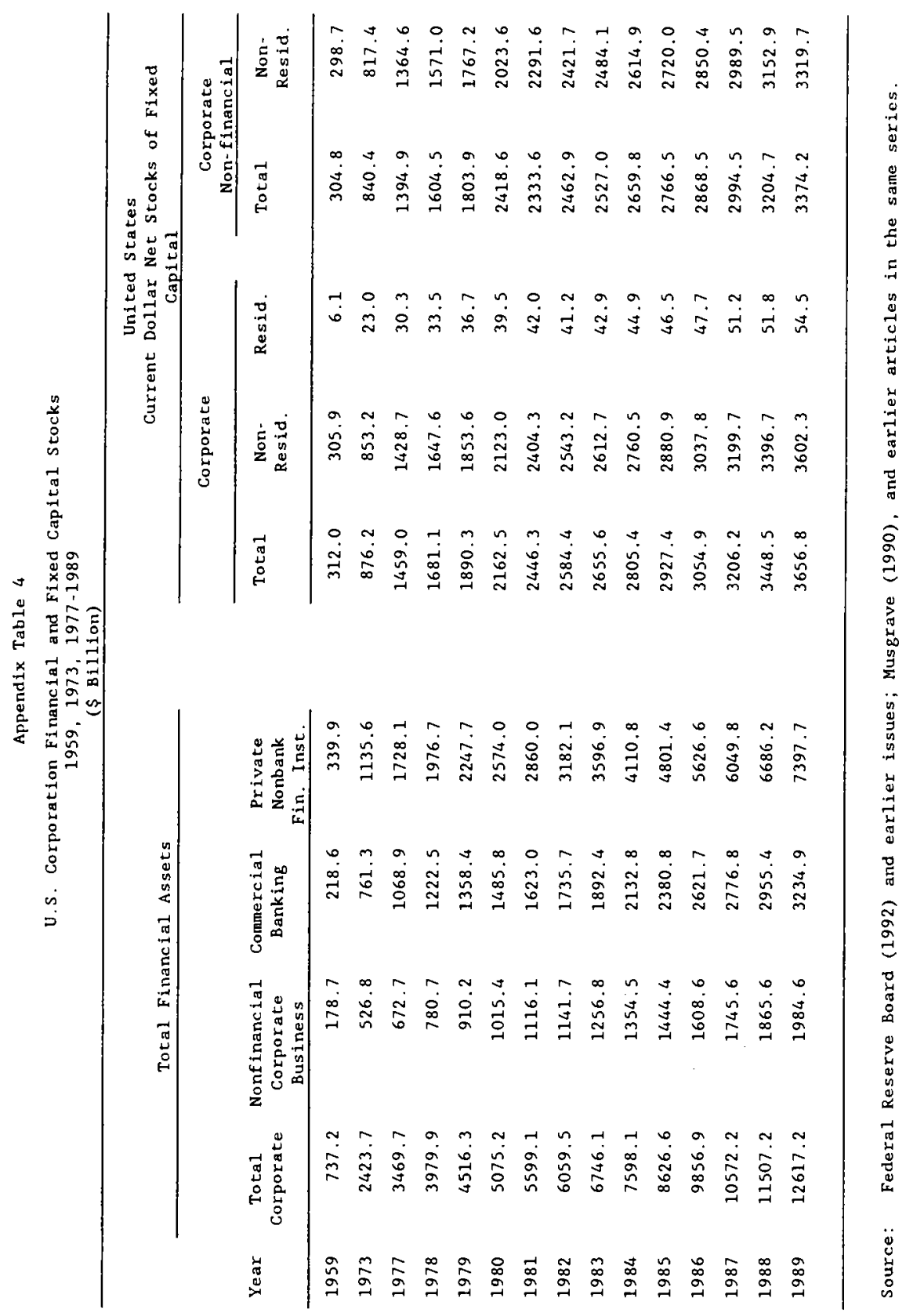


Appendix Table 5

Total Assets of Foreign Affiliates
1959, 1973, 1977-1989
(\$ Billion)

\begin{tabular}{lrrr}
\hline Year & $\begin{array}{r}\text { Total Non-bank } \\
\text { Affiliates }\end{array}$ & $\begin{array}{r}\text { Finance other } \\
\text { than }\end{array}$ & $\begin{array}{r}\text { Total excl. } \\
\text { Finance }\end{array}$ \\
\hline 1959 & $9.6^{\mathrm{a}}$ & NA & NA \\
1973 & $93.6^{\mathrm{b}}$ & 26.3 & 67.3 \\
1977 & 143.5 & 33.8 & 109.7 \\
1978 & 181.2 & 46.7 & 134.5 \\
1979 & 228.6 & 58.9 & 169.7 \\
1980 & $291.3^{c}$ & 87.7 & 203.6 \\
1981 & 407.0 & 110.2 & 296.8 \\
1982 & 476.4 & 142.6 & 333.8 \\
1983 & 531.7 & 179.2 & 352.5 \\
1984 & 602.5 & 254.0 & 348.5 \\
1985 & 741.1 & 355.7 & 385.4 \\
1986 & 838.0 & 407.2 & 430.8 \\
1987 & 943.7 & 469.9 & 473.8 \\
1988 & 1200.8 & 574.9 & 625.9 \\
1989 & 1402.2 & 641.8 & 760.4 \\
& & & \\
\hline
\end{tabular}

Sources: 1959: U.S. Dept. of Commerce (1962) Table 9.

1973: U.S. Dept. of Commerce (1976) Table G1.

1977-1980: U.S. Dept. of Commerce (1985) Table B1.

1981-1989: U.S. Dept, of Commerce (1991c) and earlier volumes

in the same series, Table B1.

Note: a, Includes banking.

b. Banking affiliate assets were $\$ 40.6$ billion.

c. Banking affiliate assets were $\$ 229.9$ billion (U.S. Dept. of Commerce, 1983, Table 5). 


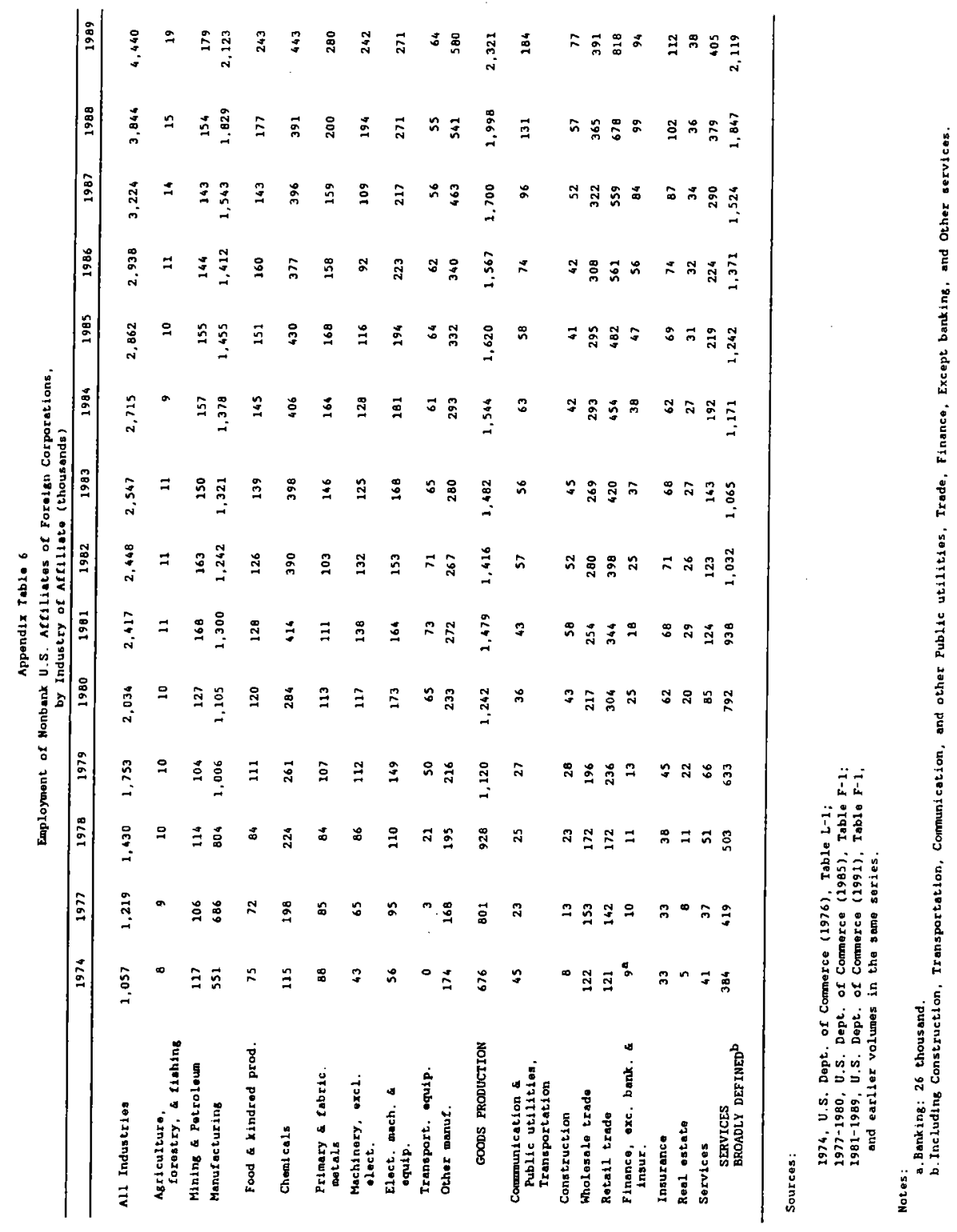




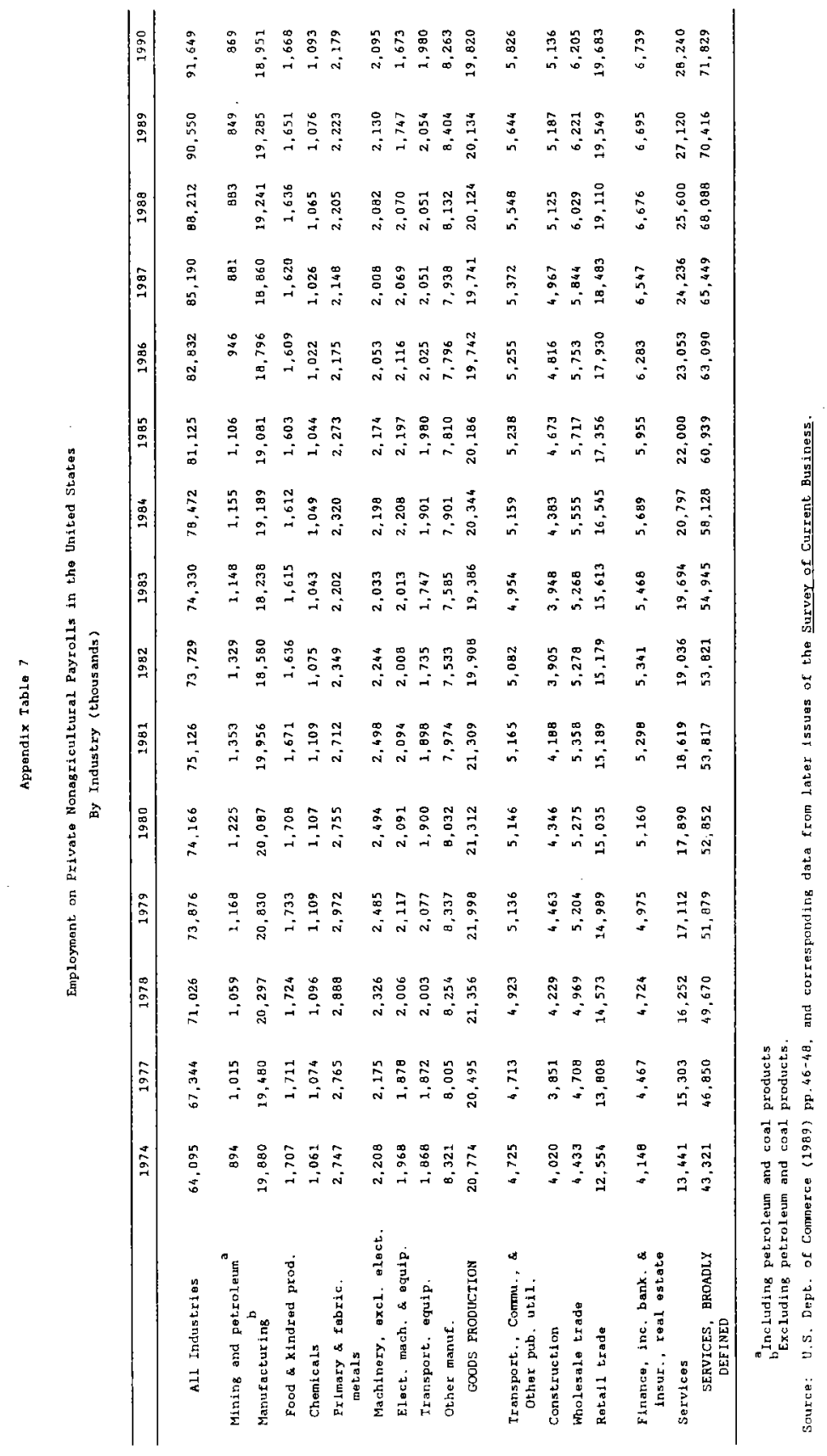


Exports and Imports of Merchandise From and Into the U.S. and Total Sales by U.S. Manufacturing Affiliates of Foreign Firms, 1974 and 1977 to 1989 ( $\$$ million)

\begin{tabular}{rrrr}
\hline YEAR & EXPORTS & IMPORTS & \multicolumn{1}{c}{ SALES } \\
1974 & 2,026 & 3,059 & 31,301 \\
1977 & 3,557 & 5,624 & 50,489 \\
1978 & 4,521 & 7,193 & 62,930 \\
1979 & 6,548 & 8,668 & 81,245 \\
1980 & 9,048 & 10,413 & 98,162 \\
1981 & 13,590 & 13,226 & 139,439 \\
1982 & 12,883 & 12,386 & 141,529 \\
1983 & 12,045 & 14,021 & 158,115 \\
1984 & 13,078 & 18,172 & 176,395 \\
1985 & 12,849 & 18,635 & 185,895 \\
1986 & 12,805 & 20,617 & 190,619 \\
1987 & 14,890 & 23,420 & 220,702 \\
1988 & 25,192 & 32,762 & 280,716 \\
1989 & 31,281 & 39,227 & 347,023
\end{tabular}

Sources: 1974: U.S. Dept. of Commerce,(1976), 1977-1980: U.S. Dept. of Commerce (1985); 1981-89: U. S. Dept. of Commerce (1991c) and earlier issues in the same series, Tables E3, G3, and G6. 
Appendix Table 9

U.S. Manufacturing Exports (Millions of U.S. Dollars)

\begin{tabular}{|c|c|c|c|c|c|c|c|c|}
\hline & TOTAL & FOOD & CHEMICAL & METALS & $\begin{array}{l}\text { NON- } \\
\text { ELEC . } \\
\text { MACH. }\end{array}$ & $\begin{array}{l}\text { ELEC. } \\
\mathrm{MACH}\end{array}$ & $\begin{array}{c}\text { TRANSP } \\
\text { EQUIP }\end{array}$ & $\begin{array}{l}\text { OTHER } \\
\text { MANUF. }\end{array}$ \\
\hline \multicolumn{9}{|c|}{ UN TAPE DATA } \\
\hline 1966 & 22,827 & 1,985 & 2,909 & 2,717 & 4,759 & 1,800 & 4,480 & 4,177 \\
\hline 1977 & 94,889 & 7,236 & 11,452 & 7,139 & 19,803 & 9,487 & 22,466 & 17,306 \\
\hline 1982 & 164,234 & 10,896 & 21,894 & 13,058 & 37,641 & 27,385 & 33,073 & 30,287 \\
\hline 1983 & 257,005 & 10,798 & 21,682 & 11,237 & 32,754 & 17,517 & 34,047 & 28,970 \\
\hline 1984 & 268,202 & 10,862 & 24,496 & 10,766 & 36,361 & 19,698 & 36,394 & 29,625 \\
\hline 1985 & 169,220 & 9,925 & 22,013 & 9,759 & 37,028 & 18,554 & 42,717 & 29,224 \\
\hline 1986 & 176,558 & 11,289 & 23,007 & 9.049 & 36,395 & 20,243 & 43,382 & 33,193 \\
\hline \multicolumn{9}{|c|}{ SHORTCUT METHOD } \\
\hline 1986 & 170,080 & 9.076 & 23,680 & 6,408 & 36,971 & 18,891 & 43,544 & 31,511 \\
\hline 1987 & 298,892 & 9,900 & 27,374 & 8,004 & 42,420 & 22,539 & 50.329 & 38,326 \\
\hline 1988 & 248,294 & 12,613 & 33,406 & 11,312 & 53,614 & 29,757 & 59,178 & 48,415 \\
\hline 1989 & 269,720 & 22,891 & 38,043 & 14,281 & 56,287 & 30,182 & 62,331 & 55,705 \\
\hline
\end{tabular}

Sources: 1966-1986, UN trade tapes. Shortcut method -. United Nations (2990a) Special Table D; (1990b); and (1991a). 


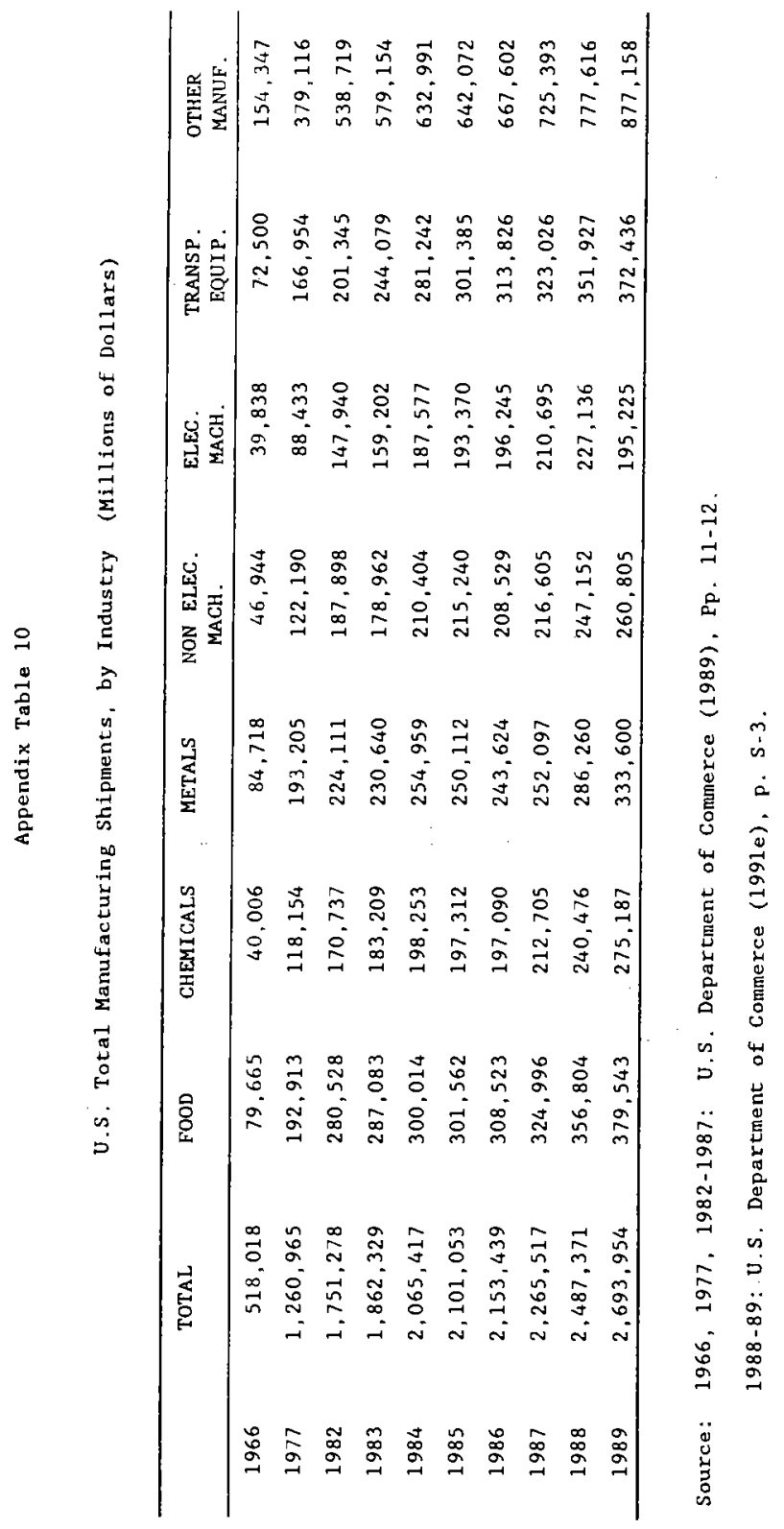


Appendix Table 11

U.S. Manufacturing Plant and Equipment Expenditures, by Industry, 1970-1989 (B1llions of Dollars)

\begin{tabular}{|c|c|c|c|c|c|c|c|c|}
\hline & $\begin{array}{r}\text { Manufac- } \\
\text { curing }\end{array}$ & Eood & Chemicals & Metals & $\begin{array}{r}\text { Non Elec. } \\
\text { Mach. }\end{array}$ & $\begin{array}{l}\text { Elec. } \\
\text { Mach. }\end{array}$ & $\begin{array}{r}\text { Transp. } \\
\text { Equip. }\end{array}$ & $\begin{array}{l}\text { Oether } \\
\text { Manuf. }\end{array}$ \\
\hline 2970 & 23.54 & 2.50 & 3.06 & 2.55 & 3.29 & 2.18 & 2.04 & 7.92 \\
\hline 1971 & 22.86 & 2.49 & 3.25 & 2.44 & 2.59 & 1.82 & 2.34 & 7.93 \\
\hline 1972 & 29.20 & 3.13 & 3.92 & 3.19 & 3.11 & 2.34 & 2.66 & 10.85 \\
\hline 1973 & 32.56 & 3.11 & 4.46 & 3.43 & 3.42 & 2.84 & 3.12 & 12.18 \\
\hline 1974 & 38.01 & 3.25 & 5.69 & 4.95 & 4.42 & 2.97 & 3.75 & 12.98 \\
\hline 1975 & 38.06 & 3.39 & 6.11 & 5.83 & 4.67 & 2.42 & 3.36 & 12.28 \\
\hline 1976 & 40.86 & 3.75 & 6.68 & 5.97 & 5.03 & 2.62 & 3.62 & 13.19 \\
\hline 1977 & 46.29 & 4.18 & 6.83 & 5.69 & 5.76 & 3.28 & 5.32 & 15.23 \\
\hline 1978 & 52.12 & 4.87 & 7.10 & 5.87 & 6.29 & 3.98 & 6.40 & 17.61 \\
\hline 1979 & 62.30 & 5.06 & 8. 56 & 6.57 & 8.41 & 5.17 & 7.75 & 20.78 \\
\hline 1980 & 89.80 & 7.39 & 12.60 & 10.40 & 11.59 & 9.59 & 18.16 & 20.07 \\
\hline 1981 & 101.66 & 8.41 & 12.62 & 11.39 & 13.09 & 11.07 & 18.79 & 26.29 \\
\hline 1982 & 92.99 & 7.74 & 23.27 & 10.05 & 12.89 & 10.62 & 15.16 & 23.26 \\
\hline 1983 & 88.05 & 6.60 & 13.28 & 8.61 & 12.35 & 10.90 & 13.02 & 23.29 \\
\hline 1984 & 113.29 & 8.82 & 25.32 & 10.59 & 15.41 & 14.61 & 16.18 & 32.36 \\
\hline 1985 & 126.47 & 10.29 & 16.45 & 11.29 & 15.97 & 15.57 & 19.29 & 37.61 \\
\hline 1986 & 124.77 & 10.60 & 16.81 & 11.13 & 13.61 & 14.17 & 18.88 & 39.57 \\
\hline 1987 & 128.52 & 11.04 & 16.37 & 12.63 & 13.77 & 15.26 & 16.74 & 42.71 \\
\hline 1988 & 144.28 & 12.69 & 18,29 & 14.55 & 14.93 & 18.01 & 16.43 & 49.38 \\
\hline 1989 & 153.70 & 15.90 & 18.50 & 12.00 & 14.60 & 20.50 & 18.70 & 53.50 \\
\hline
\end{tabular}

Note: Manufacturing excl. petroleum.

Sources: Seskin and Sulzivan (1988) and earlier articles in that serfes.

U. S. Bureau of the Census (1991), Table 897 . 
Appendix Table 12

Property, Plane and Equipment Expenditures by U.S. Manufacturing Affiliates of Foreign Firms, 1974-1989

(Billions of Dollars)

\begin{tabular}{ccccccccc}
\hline & $\begin{array}{c}\text { Manufac. } \\
\text { curing }\end{array}$ & Food & Chemicals & Merals & $\begin{array}{c}\text { Non. Elec. } \\
\text { Mach. }\end{array}$ & $\begin{array}{c}\text { Elec. } \\
\text { Mach }\end{array}$ & $\begin{array}{c}\text { Transp. } \\
\text { Equip. }\end{array}$ & $\begin{array}{c}\text { Ocher } \\
\text { Manuf. }\end{array}$ \\
\hline 1974 & 2.36 & 0.18 & 0.89 & 0.52 & $c$ & c & $0.22^{c}$ & 0.55 \\
$1977^{\mathrm{n}}$ & 2.95 & 0.25 & 1.18 & 0.37 & 0.22 & 0.20 & NA & $0.72^{\mathrm{b}}$ \\
$1978 \mathrm{a}$ & 4.04 & 0.39 & 1.71 & 0.47 & 0.26 & 0.25 & 0.04 & 0.92 \\
$1979 \mathrm{a}$ & 5.72 & 0.47 & 2.49 & 0.67 & 0.34 & 0.59 & 0.13 & 1.03 \\
1980 & 8.02 & 0.68 & 2.99 & 0.81 & 0.46 & 1.00 & 0.24 & 1.84 \\
1981 & 10.45 & 0.53 & 4.73 & 1.18 & 0.66 & 1.03 & 0.39 & 1.93 \\
1982 & 10.48 & 0.61 & 4.85 & 0.99 & 0.61 & 0.99 & 0.62 & 1.81 \\
1983 & 9.05 & 0.67 & 3.88 & 0.87 & 0.56 & 0.78 & 0.40 & 1.89 \\
1984 & 10.48 & 0.80 & 4.49 & 0.93 & 0.48 & 1.25 & 0.62 & 1.91 \\
1985 & 11.30 & 0.74 & 4.80 & 1.30 & 0.53 & 1.35 & 0.45 & 2.13 \\
1986 & 11.09 & 0.85 & 4.32 & 1.18 & 0.42 & 1.38 & 0.97 & 1.97 \\
1987 & 15.82 & 0.87 & 5.49 & 1.57 & 0.89 & 1.44 & 1.72 & 3.84 \\
1988 & 20.69 & 1.32 & 7.05 & 2.29 & 1.26 & 2.01 & 1.62 & 5.14 \\
1989 & 25.10 & 1.75 & 9.32 & 3.22 & 1.93 & 2.10 & 1.12 & 5.66 \\
\hline
\end{tabular}

Source: 1974: U.S. Dept, of Commerce (1976), Table I8, p. 123.

1977.1980: U.S. Dept. of Comperce (1985).

1981-1989: U.S. Dept. of Commerce (1991c) and earlier volumes in the same series, Table D 25, Col, 1, or Table D 29, Col. 1.

Notes: a. Plant and Equipment Expenditures. Property, plant, and equipment expenditure was 8 per cent higher In 1980.

b. Includes transp. equip.

c. Machinery inc. non-elec. mach., elec. mach. and transp, equip.. 


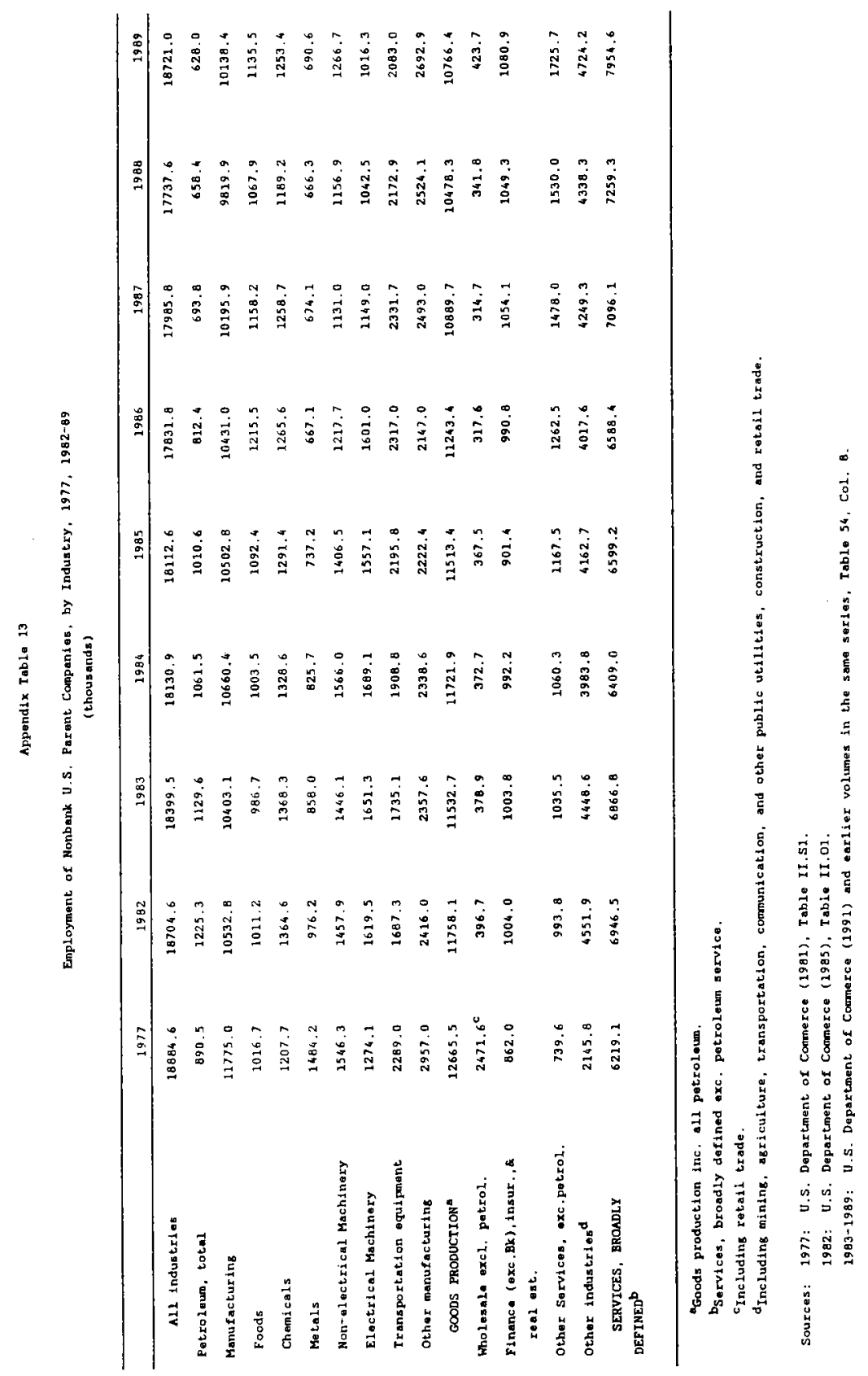


Assets of U.S. Affillates of Forelgn Firms,

by Industry and Investing Country

$1959,1974,1980$, and 1987

(Unit: $\$$ million)

\begin{tabular}{|c|c|c|c|c|c|c|c|}
\hline & WORLD & CANADA & FRANCE & GERMNANY & $\begin{array}{l}\text { NETHER- } \\
\text { LANDS }\end{array}$ & $\begin{array}{c}\text { UNITED } \\
\text { KINGDOM }\end{array}$ & JAPAN \\
\hline & \multicolumn{7}{|c|}{1959} \\
\hline AlI Industries & 9.598 & 2,575 & - & -- & 3,345 & $1,481^{\circ}$ & -- \\
\hline Mining & 237 & 66 & -- & -. & -- & 111 & -- \\
\hline Fatroloun & 3.220 & $28 \theta$ & 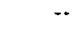 & -- & 2.184 & 13 & $\because$ \\
\hline Manufacturting & 3.921 & 1,272 & $\cdots$ & -- & 464 & 978 & - \\
\hline Wholesel, and Retail Trade & 2.359 & 350 & -- & -- & 72 & 201 & -- \\
\hline \multirow[t]{2}{*}{ Oether Industries } & 861 & 600 & 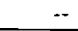 & $\because$ & 25 & 119 & -- \\
\hline & \multicolumn{7}{|c|}{1974} \\
\hline A1: Induscel $* 8$ & 174,212 & 23.856 & 8.692 & 8.201 & 27.323 & 32.226 & 39,069 \\
\hline Mining & 4,396 & 670 & - & - & - & 2,937 & 0 \\
\hline Focroloum & 28,499 & 1.638 & - & 12 & 9.958 & 4.264 & 1,867 \\
\hline Manulacturing & 26.223 & 6.936 & 1,683 & 2,347 & 2,909 & 6.550 & 2.384 \\
\hline Food & 3.864 & 2.597 & NA & 5 & 299 & 603 & 142 \\
\hline Chemicels & 7,895 & 264 & 412 & 2,503 & 2.134 & 2,046 & NA \\
\hline Metals & 4.562 & 950 & NA & 130 & 363 & 1,289 & NA \\
\hline Machinary & 3.511 & 956 & 100 & 200 & 459 & 460 & is \\
\hline Orhar masufacturing & 6.600 & 1.269 & 251 & 509 & 654 & 2,172 & MA \\
\hline Wholesale trede & 23,868 & 1,905 & 2,097 & 1,838 & 1,126 & 2,170 & 10,471 \\
\hline Recail crade & 2,259 & 351 & 26 & - & - & 1,156 & - \\
\hline Finarce, Insur.. Reel Estate & 84.758 & 13.393 & 4.500 & 3,856 & 2,085 & 15,628 & 24,360 \\
\hline other Industries & 4.279 & 962 & $586^{b}$ & $168^{c}$ & $1,245^{\mathrm{c}}$ & 822 & $987^{\mathrm{d}}$ \\
\hline
\end{tabular}




\begin{tabular}{|c|c|c|c|c|c|c|c|}
\hline & WORYD & CANADA & FRANCE & GERMANY & $\begin{array}{l}\text { NETHER- } \\
\text { LANDS }\end{array}$ & $\begin{array}{r}\text { UNITED } \\
\text { KINGDOM } \\
\end{array}$ & JAPAN \\
\hline & \multicolumn{7}{|c|}{1980} \\
\hline All Industries & 292,033 & 47,879 & 25.654 & 31,196 & 36,103 & 56,594 & 27,626 \\
\hline Mining & 6.813 & 3,342 & 413 & 193 & NA & 136 & 5 \\
\hline Petroloum & 44.060 & 3,368 & NA & 360 & NA & HA & 894 \\
\hline Manufacturing & 81,684 & 13,140 & 9.253 & 17,765 & 6,132 & 14.646 & 3,885 \\
\hline Food & 8,203 & 2,636 & 235 & 94 & 161 & 2.724 & 355 \\
\hline Chemitals & 26,086 & 553 & 1,793 & 10,347 & 3.023 & 5,502 & 311 \\
\hline Motals & 10,277 & 1,869 & 1,704 & 1,288 & NA & 1,141 & 1,194 \\
\hline Machinery, oxc. elact. & 7,645 & 3.966 & 311 & 1,045 & \} & 1,664 & 501 \\
\hline Eloc.\& electro. equip. & 9,782 & \}$^{3,966}$ & 311 & 2,433 & 2,218 & 1.053 & 399 \\
\hline Irangp. equip. & 4,476 & 4,116 & 2,521 & 2,560 & 4 & 7 & $\{1,125$ \\
\hline Other Manufacturing & 15,214 & & 2,689 & 1,999 & NA & 2,565 & ) $+1+2$ \\
\hline Wholosale trade & 50,068 & 1,898 & 5,108 & 5,459 & 688 & 5,064 & 18,724 \\
\hline Retail trada & 9,685 & 820 & NA & 1,788 & 744 & $\mathrm{NA}$ & 161 \\
\hline Ftnance except banking & 32.291 & 5,051 & NA & 495 & 1,061 & 4,706 & 2,082 \\
\hline Insurance & 36,240 & 9,869 & 255 & 2,938 & 3,513 & 9,872 & 375 \\
\hline Real Estate & 19,872 & 7.764 & 416 & 1,153 & 2,056 & 1,938 & 654 \\
\hline Services & 4,372 & 409 & 785 & 148 & 452 & 765 & 367 \\
\hline \multirow[t]{2}{*}{ Other Industries } & 6,948 & 2,218 & 1,068 & 894 & NA & 659 & 279 \\
\hline & \multicolumn{7}{|c|}{1987} \\
\hline All Industries & 963,654 & 142,506 & 34,675 & 61.168 & 68,929 & 159,525 & 200.385 \\
\hline Mining & 12,912 & 3,006 & a & 892 & $\mathrm{NA}$ & 3,302 & 26 \\
\hline Patzolaus & 79,666 & 3,364 & 4,415 & 1,134 & $\mathrm{NA}$ & 25,387 & 906 \\
\hline Manufacturing & 223,462 & 50,744 & 16,781 & 28,353 & 13,025 & 48.971 & 15,729 \\
\hline Food & 24.048 & 7,010 & 1,195 & 99 & $\mathrm{NA}$ & 7,785 & 541 \\
\hline Chemicals & 77,352 & kn & 3,681 & 14.112 & NA & 12,982 & 2,557 \\
\hline Metals & 23,170 & 4,911 & 550 & 1,926 & NA & 2,723 & 2,860 \\
\hline Machinary, exc, Glect. & 13.062 & 3,228 & 3499 & 5,753 & NA & 2,482 & 2,851 \\
\hline Elac. s olectzo. equip. & 20,372 & & & & NA & 2,735 & 1,796 \\
\hline Iransp. өquip. & 7,689 & kn & 2,791 & 510 & HA & 998 & 2,406 \\
\hline Other Manufacturing & 57,770 & NA & 5,065 & 5,953 & $\mathrm{NA}$ & 19,265 & 2,719 \\
\hline Wholesale crade & 100,740 & 4,040 & 5,769 & 11,333 & 1,173 & 13,557 & 46,561 \\
\hline Retail trade & 26.748 & 9,514 & 461 & 3,982 & 4,235 & 2,547 & 635 \\
\hline Finance except banking & 271,044 & 8,976 & 3,463 & 4,345 & 1,483 & 27,878 & 119,789 \\
\hline Insurance & 109,179 & 34,051 & 339 & 5,318 & 12,946 & 20,449 & 699 \\
\hline Resl Estate & 69,682 & 23,033 & 410 & 2,493 & 4,067 & 9,091 & 10,147 \\
\hline Services & 32,572 & 1,727 & 1,167 & 2,063 & 495 & 6.260 & 4,070 \\
\hline Other Industries & 17,648 & 4,051 & $1,891^{\circ}$ & 1,254 & NA & 2,084 & 2,824 \\
\hline
\end{tabular}


Notes to Appendix Table 14

${ }^{a}$ Included in other industries

${ }^{b}$ Includes mining and petroleum

${ }^{c}$ Includes mining and retail trade

dincludes retail trade

Includes mining

Sources: U.S. Department of Commerce (1962), Table 9; (1976), Table G-13, (1983), Table B-7; (1990). Table B-5. 
Appendix Iable is

Sales of U.S. AfC1liates of Foreign Ficms,

by Industry and Investing Country

1959, 1976, 1980, and 1987

(Unit: $s$ mition)

\begin{tabular}{|c|c|c|c|c|c|c|c|c|}
\hline & \multicolumn{8}{|c|}{ COUHIRY OF PARENT } \\
\hline & WORLD & CANADA & EUROPE & France & GERMANY & $\begin{array}{l}\text { HETHER- } \\
\text { LANDS }\end{array}$ & $\begin{array}{l}\text { UNITED } \\
\text { KINGDOM }\end{array}$ & JAPAN \\
\hline INDUSTRY & \multicolumn{8}{|c|}{1959} \\
\hline Alt Industries & 8,062 & 2,512 & 5,483 & 97 & 47 & 2,919 & 1,445 & 0 \\
\hline Mining & 222 & 53 & 69 & 0 & 0 & 0 & 0 & 0 \\
\hline Petroleuse & 2,356 & 260 & 2,296 & 0 & 0 & 2,102 & 9 & 0 \\
\hline Manufacturing & 5,231 & 2,063 & 3,020 & 92 & 47 & 775 & 1,234 & 0 \\
\hline Foods & 2,295 & 1.353 & 966 & NA & 0 & NA & 654 & 0 \\
\hline Chouicals & 891 & 45 & 832 & 6 & 46 & NA & 78 & 0 \\
\hline Motals & 276 & 207 & 69 & NA & 0 & 0 & 17 & 0 \\
\hline Machinury exc. Eluce. & 432 & 238 & 189 & 0 & 0 & NA & 104 & 0 \\
\hline Eloce. Mach, \& Equip. & 289 & 1 & 208 & sA & 0 & 0 & 52 & 0 \\
\hline Orhor Marufactizing & 944 & 219 & 696 & क्षA & 0 & NA & 382 & 0 \\
\hline Ocher Industzien & 453 & 236 & 198 & 6 & 0 & 42 & 202 & 0 \\
\hline
\end{tabular}

\begin{tabular}{|c|c|c|c|c|c|c|c|c|}
\hline INDUSTRY & \multicolumn{8}{|c|}{1974} \\
\hline All Industries & 146.776 & 15.936 & 80.311 & 12,796 & 8.727 & 17,106 & 27,138 & 40.106 \\
\hline Mining & 1.409 & $c$ & 941 & S3: & 1 & 330 & 579 & 0 \\
\hline Putrolourot & 26.350 & c & 15,920 & $\leq 630$ & st9 & $\begin{array}{r}20,550= \\
12,332\end{array}$ & 2,602 & 11.296 \\
\hline Marufacturing & 31.302 & 5,881 & 21,323 & 2,004 & 2,538 & 3,882 & 7,660 & 2,311 \\
\hline E oads & 5,534 & 1,341 & 3,995 & 5723 & 3 & 569 & 1,194 & 231 \\
\hline Chomicals & 7.985 & 216 & 6,424 & 104 & 2,372 & 1,406 & 2.679 & 4 \\
\hline Metal: & 6.139 & . & 3,357 & 533 & 227 & 282 & 1,996 & 554 \\
\hline Mathinery & 4,400 & 1,250 & 2,750 & $\leq 370$ & 287 & 680 & 547 & 267 \\
\hline Other Manufacturing & 7.243 & $3,074^{d}$ & 4,007 & 285 & 950 & 964 & 2.244 & $359^{f}$ \\
\hline Wholesale Irade & 66,459 & 4,378 & 30,264 & 9,418 & 5,715 & 51,780 & 0.578 & 27,097 \\
\hline Retail Irade & 6.327 & $=$ & 3,800 & 29 & 25 & 180 & 3,116 & \\
\hline $\begin{array}{l}\text { Finance (exc, banking), } \\
\text { Insurance, Real Estate }\end{array}$ & 11,259 & $c$ & 6,377 & 630 & 316 & $: 52$ & 3,757 & \\
\hline Othwe Industrios & 3.626 & $5,675^{\circ}$ & 1,796 & $\leq 57$ & $55 y$ & 115 & 066 & 212 \\
\hline
\end{tabular}


Append1x Tablo is (continued)

\begin{tabular}{|c|c|c|c|c|c|c|c|c|}
\hline & & & COUNIR: & DF ULTIMATE & BENEFICLAL & WNER & & \\
\hline & WORLD & CANADA & EUROPE & FRANCE & GERMANY & $\begin{array}{c}\text { NETHER- } \\
\text { LANDS }\end{array}$ & $\begin{array}{l}\text { UKITED } \\
\text { KINGDOM }\end{array}$ & JAPAN \\
\hline INDUSTKY & \multicolumn{8}{|c|}{1980} \\
\hline A11 Industries & 422.390 & 35.656 & 259,624 & 40.806 & 45.620 & 38,618 & 94.610 & 36,207 \\
\hline Misine & 3,306 & 1.777 & 1.392 & $\mathrm{NA}$ & NA & NA & 123 & 0 \\
\hline Potrolaus & 36,052 & 2.465 & 47,973 & $N_{A}$ & KA & NA & 25,670 & 3,717 \\
\hline Manufacturins & 98,162 & 15.686 & 73,426 & 12,540 & 19.280 & 8.586 & 17.850 & 3,990 \\
\hline Food. & 11,956 & 2,644 & 8,282 & 202 & 202 & - & 4.858 & 455 \\
\hline Chemicels & 28,204 & 1.026 & 26.374 & 1.745 & 22.368 & 3.675 & 5.004 & 381 \\
\hline Morsals & 22.911 & 2.948 & 0.359 & 2.656 & .2 .526 & $\bullet$ & 2.224 & $2.06 \mathrm{a}$ \\
\hline Machinery axc. Elect. & 9.009 & 4,261 & 6.332 & 368 & 2.320 & 3,717 & 2.252 & 523 \\
\hline Eloct, Mach. Equlp. & 11.977 & & 6.946 & & 2.207 & & 988 & 678 \\
\hline Ir ansportation Equip. & 6.390 & $\$ 1$ & 6.253 & 7.577 & 1.609 & 4 & 20 & \\
\hline Orher Manufacturing & 17.635 & 6,767 & 10,972 & & 2.070 & $2,200^{\circ}$ & 3,625 & 803 \\
\hline Wholasele Irade & 197,676 & 5,395 & 96.675 & 18,661 & 14.104 & 1,832 & 69.236 & 75.021 \\
\hline Retasl Itade & 23.675 & 2,281 & 19.511 & NA & $\mathrm{NA}$ & $\mathrm{NA}$ & c & 190 \\
\hline Flnance (exc, barking) & 6.755 & 675 & 3.031 & NA & 38 & 26 & 492 & e \\
\hline Insurance & 16.197 & 3,106 & 9.460 & 112 & 920 & $N_{A}$ & 4.883 & e \\
\hline Real Estate & 3,933 & 2.255 & 3.027 & 126 & 278 & 294 & 281 & 107 \\
\hline Sorvices & 3.332 & 329 & 2.080 & 677 & 2,683 & 233 & 667 & 491 \\
\hline Other Industries & 7.623 & 1,308 & 4.869 & NA & $\mathrm{NA}$ & NA & $5,360^{h}$ & $695^{i}$ \\
\hline
\end{tabular}

\begin{tabular}{|c|c|c|c|c|c|c|c|c|}
\hline I INDUSTRY & \multicolumn{8}{|c|}{1987} \\
\hline All Industries & 766.617 & a9, 433 & 393,132 & 44,113 & 74,259 & 52.373 & 232.233 & 186.822 \\
\hline Mining & 3,757 & $\therefore, 670$ & 2.758 & NA & 900 & NA & 2.215 & $\$ 102$ \\
\hline Petzolungon & 72.993 &, \pm 323 & 52,324 & NA & NA & $N_{A}$ & 25.896 & 2,169 \\
\hline Manufacturing & 225.079 & 43.705 & 146.878 & 26.906 & 30,676 & 26,832 & 47.975 & 25.696 \\
\hline Foods & 22.962 & 3.376 & 27.967 & 2,106 & 126 & NA & 8,201 & 612 \\
\hline Cheoricals & 72,105 & NA & 262,803 & 2.091 & 14,961 & NA & 12,811 & 2.136 \\
\hline Motals & 26.658 & 3.956 & 9.372 & 669 & 2,986 & 126 & 2,795 & 3,600 \\
\hline Machinery exc. Elect. & 13,766 & 1.291 & 9.405 & 3.169 & 2.619 & 276 & 2.423 & 2.320 \\
\hline Elect, Mach, \& Equip. & 26,577 & & 19.895 & & 4.260 & NA & 2.717 & 2.721 \\
\hline Iransportation Equip. & 8,384 & NA & 5.737 & 3.618 & 562 & 2 & 1,239 & 4.110 \\
\hline Other Manufacturing & 54.727 & $30.386^{6}$ & 542.699 & 4.273 & 6.236 & 912 & 17,790 & \\
\hline Wholosele Irado & 278,843 & 0,786 & 105,596 & 10.556 & 23.232 & 2,917 & 39.270 & 132,000 \\
\hline Retal I Irade & 48,433 & 13.720 & 30.847 & 2,355 & 20.943 & 6.799 & 4.439 & 642 \\
\hline Flnane (exe. banking) & 27,008 & 782 & 11.606 & 317 & 345 & 231 & 3.524 & 11.765 \\
\hline Insuranes & 39.260 & 10.869 & 20.076 & 167 & 1,920 & 4.720 & 8.427 & 297 \\
\hline Real Eatate & 20,907 & 4,588 & 3.358 & 15: & 412 & 689 & 1.466 & 745 \\
\hline Sarvicos & 20,086 & 2,267 & 12,606 & 716 & 979 & 461 & 7.080 & 2.360 \\
\hline Other Indust ftas & 37.252 & 2.766 & 0.096 & $\mathrm{NA}$ & $3.053^{\mathrm{J}}$ & 2599 & 2.090 & 3.236 \\
\hline
\end{tabular}




\section{Notes to Appendix Table 15}

${ }^{a}$ Included in other manufacturing

${ }^{b}$ Including Foods

cIncluded in other industries

$\mathrm{d}_{\text {Including Metals }}$

encluding Metals and Foods

$f_{\text {Including Chemicals and Transportation }}$

Including Mining, Petroleum, Retail Trade, and Finance (exc. banking), Insurance, and Real Estate

hIncluding Retail Trade

${ }^{i}$ Including Finance (exc. banking) and Insurance

jIncluding Petroleum

Sources: U.S. Department of Commerce (1962), Tables 13 and 14; (1976), Table K-5; (1985), Table E-5; and (1990), Table E-3. 
Appendix Table 16

Expenditures For Property, Plant, and Equipment by U.S. Affiliates

of Foreign Finms by Industry and Investing Country 1974, 1980, and 1987

(Unit: $\$$ million)

\begin{tabular}{|c|c|c|c|c|c|c|c|}
\hline & COALL & CANADA & BRANCE & GERMANY & $\begin{array}{l}\text { NEIHER- } \\
\text { LANDS }\end{array}$ & $\begin{array}{l}\text { UNITED } \\
\text { KINGDOM }\end{array}$ & JAPAN \\
\hline & \multicolumn{7}{|c|}{1974} \\
\hline All industries & 7,716 & 893 & 370 & 373 & 2.295 & 1,388 & 721 \\
\hline Mining & 505 & 110 & 4 & a & $\Delta$ & 278 & 0 \\
\hline Fetroleum & 2,858 & - & - & 3 & 1,842 & 438 & a \\
\hline Manufacturing & 2,358 & 313 & 158 & 224 & 291 & 457 & 299 \\
\hline Food & 179 & 66 & 8 & 2 & 16 & 46 & 16 \\
\hline Chemicals & 887 & 20 & \multirow{2}{*}{114} & 158 & 139 & 148 & 32 \\
\hline Metals & 520 & 78 & & 11 & 60 & 93 & NA \\
\hline Machinery & 218 & 34 & 8 & 15 & 34 & 30 & 49 \\
\hline Othar Manufactusing & 555 & 145 & 28 & 39 & 41 & 140 & HA \\
\hline Wholosale trade & 519 & 49 & 49 & 33 & 15 & 53 & a \\
\hline Retail trade & 160 & a & 1 & 1 & $\mathbf{a}$ & 61 & 16 \\
\hline Finance (exc. banking) & 748 & 265 & 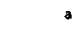 & 69 & 44 & $\mathbf{a}$ & $a$ \\
\hline Other industries & 568 & $256^{c}$ & $158^{d}$ & $43^{\circ}$ & $103^{1}$ & $101^{8}$ & 406 \\
\hline & \multicolumn{7}{|c|}{1980} \\
\hline All industries & 25,713 & 6,427 & 1,883 & 2,981 & 4.048 & 3,547 & 1,652 \\
\hline Mining & 567 & 284 & 78 & 12 & a & 10 & 0 \\
\hline Patroloum & 5,404 & 893 & 126 & 67 & $a$ & a & 3 \\
\hline Manufacturing & 7,971 & 1,407 & 733 & 2.024 & 460 & 1,301 & 516 \\
\hline Foad & 681 & 280 & 8 & 10 & NA & 146 & 42 \\
\hline Chemicals & 2,977 & 55 & 184 & 1,458 & NA & 672 & 50 \\
\hline Metals & 810 & 179 & 120 & 64 & NA & 52 & NA \\
\hline Machinary, exc. elact. & 448 & 313 & 23 & 105 & 228 & 91 & NA \\
\hline E1ec. \& electro. equip. & 1,004 & & & 93 & & 85 & $\mathrm{NA}$ \\
\hline Trensp. equip. & 269 & 5.80 & 128 & 99 & 1 & 1 & NA \\
\hline Other Manufacturing & 1.802 & 200 & 270 & 196 & 23 & 254 & NA \\
\hline Wholesale trade & 1.750 & 83 & $\mathbf{a}$ & 269 & - & 193 & 412 \\
\hline Retail trade & 823 & 100 & a & 131 & 55 & a & 27 \\
\hline Finance (exc. bank1ng) & 254 & - & $\mathbf{a}$ & 1 & 0 & 16 & a \\
\hline Insuranc* & 235 & - & a & 23 & $\triangle$ & 53 & 0 \\
\hline Real estate & 7,101 & 3,122 & 128 & 328 & 599 & 436 & 272 \\
\hline Services & 590 & 91 & 172 & 17 & 20 & 65 & 29 \\
\hline Other industries & 1,019 & $457^{1}$ & $646^{j}$ & 109 & $2,914^{k}$ & $1.475^{\mathrm{c}}$ & $193^{1}$ \\
\hline
\end{tabular}


Appendix Table 16 (continued)

\begin{tabular}{|c|c|c|c|c|c|c|c|}
\hline & $\begin{array}{l}\text { ALL } \\
\text { COUNTRIES }\end{array}$ & CANADA & FRANCE & GDRMANY & $\begin{array}{c}\text { NETHER- } \\
\text { LANDS }\end{array}$ & $\begin{array}{l}\text { UNITED } \\
\text { KINGDCH }\end{array}$ & JAPAN \\
\hline & \multicolumn{7}{|c|}{1987} \\
\hline All Industries & 45,657 & 9.324 & 1,613 & 3,731 & 4,472 & 7,140 & 9,587 \\
\hline Mining & 1,258 & a & 4 & 126 & 2 & 224 & 1 \\
\hline Fatroloum & 6,239 & 180 & 405 & 64 & 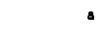 & ه & 101 \\
\hline Manufacturing & 25,819 & 4,117 & 806 & 1,816 & 670 & 2,808 & 2,607 \\
\hline Food & 870 & 155 & 85 & NA & $\mathrm{MA}$ & 333 & 65 \\
\hline Chemicals & 5,688 & $\mathrm{NA}$ & 132 & 865 & NA & 563 & 84 \\
\hline Metals & 1,567 & 228 & 15 & 112 & $\mathrm{NA}$ & 188 & 337 \\
\hline Machinery, oxe. eloct. & 391 & 296 & 237 & & 237 & 160 & 287 \\
\hline Elec.\& electro. equip. & 1,437 & & & 276 & & 246 & 237 \\
\hline Transp. quip. & 1,723 & $\mathrm{NA}$ & 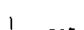 & 66 & 0 & 38 & 1,380 \\
\hline Othor Menufacturing & 3,844 & NA & (2) & NA & 26 & 1,319 & 317 \\
\hline Wholesale trade & 2,907 & 183 & 93 & 560 & 49 & 272 & 1,326 \\
\hline Rotail trade & 2,057 & 459 & 57 & 279 & 636 & 171 & 36 \\
\hline Finance (axc. banking) & 947 & 82 & 18 & 6 & $\Delta$ & 220 & 472 \\
\hline Insurance & 640 & a & 0 & 28 & $12^{\top}$ & 91 & 2 \\
\hline Real estate & 11,198 & 3,188 & 30 & 452 & a & 956 & 3,771 \\
\hline Services & 2,790 & 222 & 39 & 1000 & 21 & 319 & 1,008 \\
\hline Other industries & 1,801 & $893^{m}$ & 162 & 400 & $2,967^{n}$ & $2,279^{\circ}$ & 263 \\
\hline
\end{tabular}

Included in Other industries

bincludes Services

includes Fatroleum and Retail Irade

dincludes Petroleum and Finance. Insurance, and Real Estate

Includas Mining

Includes Mining and Retail Trade

sincludes Finarce, Insuzaree, and Real Estato

hincludes Petroloun, wholesale Trado, and Finance, Insurance, and Real Eatate

Includes Finance (exc, banking) and Insuranea

Jincludes wholesale and Retail Irade, Finance (exc. benking), and Insurance

Includes Mining, Petroleum, Wholesale Trade, and Insurance

I Includes Finance (exc, banking)

Includes Mining and Insurance

Includes Potroleun, Finance (exc. banking), and Real Escate

Inciudes Patroloum

Sourena; U.S. Dopartment of Comerce (1976), Table I-8; (1983), Tabio $0-9$; and $(2990)$, Tabl, D-2?. 
Appendix Table 17

Employwent in U.S Affillates of Foreign Fisms, by Industry and Investing Country 1974,1980 , and 1987

(Unit: thousands)

\begin{tabular}{|c|c|c|c|c|c|c|c|}
\hline & \multicolumn{7}{|c|}{ COUNTRY OF PARENT } \\
\hline & $\begin{array}{c}\text { ALL } \\
\text { COUNTRIES }\end{array}$ & CANADA & TRANCE & GEREANY & $\begin{array}{l}\text { NETHER- } \\
\text { LANDS }\end{array}$ & $\begin{array}{l}\text { UNITED } \\
\text { KI RGDOM }\end{array}$ & JAPAN \\
\hline & \multicolumn{7}{|c|}{1974} \\
\hline All industries & 1.083 .4 & 176.0 & 57.6 & 59.0 & 172.2 & 284.3 & 70.9 \\
\hline Mining & 22.7 & a & a & a & 6.0 & 8.1 & 0.0 \\
\hline Petrolous & 93.7 & $\bullet$ & a & a & a & 11.3 & a \\
\hline Manufacturing & 550.6 & 92.3 & 33.7 & 42.6 & 86.3 & 132.6 & 21.3 \\
\hline Food & 74.7 & 15.7 & NA & 0.1 & NA & 21.2 & NA \\
\hline Chemicals & 114.7 & 1.7 & 4.1 & 21.4 & 24.6 & 23.9 & NA \\
\hline Metals & 87.8 & 17.0 & NA & 2.7 & NA & 28.1 & NA \\
\hline Machinery & 99.6 & 23.2 & 3.4 & 4.0 & 19.2 & 12.4 & 7.0 \\
\hline Dehar Manufacturing & 173.8 & 34.8 & 5.3 & 14.6 & 29.0 & 47.0 & 5.0 \\
\hline Wholesale trade & 121.9 & 29.0 & 8.4 & 9.7 & 14.1 & 17,5 & 23.4 \\
\hline Retail trade & 120.5 & a & 0.3 & 0.4 & a & 61.0 & a \\
\hline \multirow{5}{*}{$\begin{array}{l}\text { Finance (exc.banking), } \\
\text { Insur. and } R E \\
\text { Other industries }\end{array}$} & 72.6 & 9.5 & 1.9 & 4.2 & 1.2 & 27.3 & 4.8 \\
\hline & 101.3 & $55.2^{c}$ & $13.5^{d}$ & $3.3^{\mathrm{d}}$ & $64.6^{\circ}$ & 26.5 & $21.4^{\circ}$ \\
\hline & \multicolumn{7}{|c|}{ COUNTRY OF ULTIMATE BENEFICIAL OWNER } \\
\hline & $\begin{array}{c}\text { ALL } \\
\text { COUNTRIES }\end{array}$ & CANADA & FRANCE & GERMASY & $\begin{array}{l}\text { NETHER- } \\
\text { LANDS }\end{array}$ & $\begin{array}{l}\text { UNITED } \\
\text { KINGDOM }\end{array}$ & JAPAN \\
\hline & \multicolumn{7}{|c|}{1980} \\
\hline All industries & 2.033 .9 & 290.0 & 206.6 & 375.9 & 186.7 & 428,2 & 225.3 \\
\hline Mining & 25.2 & 11.9 & 1.2 & NA & $\mathbf{a}$ & 988.0 & a \\
\hline Patrolaw & 101.1 & 11.6 & 5.9 & 1.4 & a & $\mathbf{a}$ & 0.2 \\
\hline Manufacturing & $1,105.0$ & 152.8 & 119.0 & 239.0 & 102.6 & 224.0 & 36.2 \\
\hline Food & 120.4 & 19.5 & 1.6 & 1.1 & 3.1 & 58,7 & 4.9 \\
\hline Chemicals & 283.8 & 4.3 & 15.4 & 234.4 & NA & 47.5 & 2.6 \\
\hline Metals & 112.9 & 20.2 & 20.4 & 14.2 & NA & 26.5 & 0.3 \\
\hline Machinery. exc. elect, & 116.9 & 20.6 & 2.8 & 17.6 & & 32.8 & 5.1 \\
\hline Elec. \& electro. equip. & 172.5 & 30.3 & 2.7 & 16.7 & 58.8 & 17.2 & 7.2 \\
\hline Transp. equip. & 65.1 & 0.7 & & & & 0.2 & \\
\hline Other Manufacturing & 232.6 & 57.1 & 76.2 & 55.2 & 4.3 & 52.2 & 16.2 \\
\hline Wholesale trado & 217.2 & 14.5 & 28.2 & 33.4 & 3.7 & 35.0 & 54.7 \\
\hline Retail trade & 304.2 & 35.9 & 0.6 & MA & 21.1 & a & 3.7 \\
\hline Finance (exc. banking) & 24.8 & a & $a$ & 0.2 & & 6.1 & 2.5 \\
\hline Insurance & 62.3 & 8.4 & 0.2 & 2.9 & 8.6 & 27.8 & a \\
\hline Real estate & 19.7 & 33.6 & 0.3 & 0.2 & 0.7 & 1.1 & 0.4 \\
\hline Services & 85.3 & 10.3 & 5.5 & 2.6 & 3,5 & 11.7 & 10.3 \\
\hline Other industries & 88.6 & $31 \cdot 0^{8}$ & $45.7^{8}$ & $96.2^{h}$ & $46.5^{f}$ & $11.9^{\circ}$ & 8. $3^{j}$ \\
\hline
\end{tabular}


Append1x Table 17 (continued)

\begin{tabular}{|c|c|c|c|c|c|c|c|}
\hline & \multicolumn{7}{|c|}{ COUNTRY OF ULTIMATE BEKEFICIAL OWNER } \\
\hline & $\begin{array}{c}\text { ALL } \\
\text { COUNTRIES }\end{array}$ & CANADA & FRANCE & GERMANY & $\begin{array}{l}\text { NETHER- } \\
\text { LANDS }\end{array}$ & $\begin{array}{l}\text { UNITED } \\
\text { KINGDOM }\end{array}$ & JAPAN \\
\hline & \multicolumn{7}{|c|}{1987} \\
\hline All industries & $3,224,3$ & 592.9 & 187.8 & 366.6 & 270.1 & 647.4 & 303.2 \\
\hline Mining & 27.6 & 8.5 & 0.5 & 3.0 & 0.4 & 6.1 & 0.2 \\
\hline Fotroleun & 124.9 & 2.2 & a & 1.1 & $b$ & 44.8 & 0.3 \\
\hline Manufacturing & 1.542 .6 & 275.1 & 110.1 & 193.9 & 93.5 & 391.2 & 86.9 \\
\hline Food & 242.6 & 21.7 & 7.9 & 0.6 & NA & 53.6 & 3.7 \\
\hline Chamicals & 395.8 & $a$ & 12.0 & 76.2 & NA & 88.0 & 11.3 \\
\hline Motals & 159.3 & 33.5 & 4.2 & 16.1 & 1.0 & 20.6 & 17.8 \\
\hline Machiners, exc. olect. & 109.3 & & & 47.2 & 5.9 & 21.8 & 16.3 \\
\hline Elec \& electro. equip. & 216.8 & 33.6 & 36.4 & 35.0 & NA & 31.7 & 12.5 \\
\hline$T$ Fansp. equip. & 55.7 & $1863^{1}$ & 20.6 & 3.3 & 0.0 & 23.5 & 7.7 \\
\hline Other Manufacturing & 463.0 & $18 b .3$ & 29.0 & 50.4 & 7.8 & 161.9 & 17.6 \\
\hline Wholesale trade & 321.9 & 18.3 & 29.0 & 50.3 & 7.8 & 45.8 & 108.6 \\
\hline Retail trada & 558.7 & 185.7 & 13.6 & 92.2 & 210.0 & 47.8 & 9.2 \\
\hline Finance (exc. banking) & B3. 9 & 1.9 & 0.5 & 0.6 & 0.5 & 12.4 & 44.0 \\
\hline Insurance & 87.4 & 11.2 & 0.1 & 2.9 & 15.1 & 24.2 & 0.4 \\
\hline Real estate & 33.9 & 20.9 & 0.1 & 0.4 & 1.4 & 3.3 & 1.0 \\
\hline Services & 290.3 & 33.7 & 12.1 & 8.9 & 3.9 & 51.4 & 29.6 \\
\hline Otber industries & 163.1 & 35.4 & $21.8^{b}$ & 13.3 & $37.5^{b}$ & 20.4 & 24.0 \\
\hline
\end{tabular}

Included in other industries

Includes Services

Includes Mining, Petroleus, and Retall trade

dncludes Mining and Petroleum

Encludes Petroleum and Rotail Irado

Includes Mining, Petroleum, and Finance

Includes Finance (exce banking)

bincludes Mining and Retail

Includes Chomicals

$\mathrm{j}_{\text {Inc Iudes Mining and Insurance }}$

Sources: U.S. Department of Commerce (1976). Table L-4

U.S. Department of Commere (1985), Table F-4

U.S. Departinent of Commere (1990), Table F-3. 